\title{
SMRT DOLU SAUERSACK/ROLAVA (OKRES SOKOLOV). ZÁNIK DŮLNÍHO ZÁVODU V MEZIOBOROVÉ PERSPEKTIVĚ
}

\author{
PETR HASIL - DAVID NOVÁK - JAN HASIL
}

\begin{abstract}
Abstrakt: Přispěvek prezentuje průběžné výsledky výzkumných aktivit Archeologického ústavu AV ČR, Praha, v. v. i., a bakalářského úkolu řešeného od roku 2014 na Katedře historie UJEP v Ústí nad Labem formou prípadové studie $k$ problematice zániku a archeologizace di̊lního závodu Sauersack/Rolava (okr. Sokolov). Ten byl vybudován za účelem těžby a prvotniho zpracováni cínové rudniny v rámci válečného úsilí třetí řiše, která zde nasadila na nucené práce válečné zajatce mnoha evropských národností. Po roce 1945 nebyly těžebni a úpravnické práce obnoveny a v únoru 1946 padlo rozhodnuti o demontáži upotřebitelného vybaveni a uzavření dolu. Od léta 1947 se tak areál závodu i prilehlého zajateckého tábora postupně mění $v$ archeologickou lokalitu.
\end{abstract}

Klíčová slova: archeologie modernity - Sauersack/Rolava-druhá světová válka-archeologizace-rudné hornictví.

The Death of the Sauersack/Rolava Mine (Sokolov District). The decline of a mining plant through the prism of interdisciplinary research

Abstract: This contribution presents results yielded so far by research activities of the Archaeological Institute of the Academy of Sciences of the Czech Republic, Prague, and a bachelor's degree thesis started in 2014 at the Department of History of Jan Evangelista Purkyně University, Usti nad Labem in the form of a case study devoted to the decline and archaeologization of the Sauersack/Rolava mining plant (Sokolov district). The plant was established in order to mine and smelt tin ores, as part of the Third Reich military endeavours. Forced labour in the mine was performed by prisoners of war of many European nationalities. After 1945 the mining and smelting activities were not resumed and in February 1946 the Czechoslovak government decided to have the mining equipment dismantled and to close the mine down. In summer 1947, the complex of the mining plant and the adjacent POW camp started to turn into an archaeological site.

Key words: archaeology of modernity - Sauersack/Rolava - Second World War - archaeologization - tin ore mining.

\section{1. Úvod}

Rozdílné kategorie archeologických nálezů umožňují a zároveň vyžadují rozdílné poznání procesu archeologizace, původní zanikající a transformující se struktury však archeologie může zpravidla nejvýše modelovat (srov. např. Kuna-Němcová a kol. 2012). Z metodického hlediska je proto cenné aplikovat archeologické poznávací postupy i tam, kde je badateli podoba původní živé kultury bud' autoopticky známá či stále velmi blízká, nebo pokud ji může studovat na základě alternativní, zejména písemné, plánové a popr. obrazové dokumentace. Rozvíjení poznávání chronologicky proximálních období (modernity) prostřednictvím archeologické metody je třeba pokládat za aktuální úkol (srov. Vařeka ed. 2013), nebot’ zde se otevírá vynikající možnost rozvíjení pramenné kritiky nikoliv ve vztahu „objektivní zjištění - model“, nýbrž v rovině „objektivní zjištění - objektivní zjištěni“, tedy na úrovni obecné teorie současných artefaktů (Neustupný 2013). Zároveň je třeba připomenout, že v rámci posilování kolektivního historického vědomí občanské společnosti se již od 90 . let 20. století rozvíjí v západních zemích archeologie „temných období“, ${ }^{1}$ kdy artefaktuální rovina svou specifickou perspektivou dokresluje rámec událostí, které nesmějí být zapomenuty. Archeologie tím dostává příležitost dostát své společenské úloze (výstižně ji formulují Kolář-Macháček 2014, 550) v rámci problematiky, která je širší posluchačské obci dobře srozumitelná, a tím posiluje i obecný impakt a kredit oboru jako

1 Nejvýznamnější aktuální diskursy v tomto směru reprezentují zejména KZ-Archäologie (viz např. Kola 2000; Theune 2006; 2010; 2010a) a Dark Modernities (srov. booklet abstraktů z konference CHAT 2014: Dark Modernities konané v Plzni ve dnech 31. ŕijna - 2. listopadu 2014 a dále např. Forbes-Page-Pérez 2009; Funari-Zarankin-Salerno edd. 2010). 
celku. Př́íspěvkem k oběma výzvám, před nimiž současná archeologie stojí, má být i předkládaný text, který vznikl v rámci výzkumných aktivit Archeologického ústavu AV ČR, Praha, v. v. i., v letech 2012-2014² a bakalářského úkolu řešeného od roku 2014 na Katedře historie UJEP v Ústí nad Labem. Průběžné výsledky archeologického průzkumu a rozsáhlé archivní rešerše budou prezentovány formou př́padové studie k problematice zániku a archeologizace důlního závodu Sauersack.

\subsection{Vznik závodu a jeho vývoj do konce druhé světové války}

Hluboké bažinaté lesy severně od Přebuzi, těsně při česko-saské hranici, skrývají unikátní technickou památku - relikty cínového dolu na k. ú. Rolavy (do roku 1947 Sauersack; obr. 1), který byl vybudován berlínskou těžební společností Zinnbergbau Sudetenland, GmbH, v období druhé světové války. Cín mj. představuje důležitou surovinu pro válečnou výrobu a z tohoto důvodu došlo již v průběhu první světové války na katastru Rolavy k prospekcím místních rud barevných kovů. Jejich těžba se po skončení války a znovuobnovení dodávek importované levnější a kvalitnější rudy neukázala jako ekonomicky efektivní. Ve 20. a 30. letech těžební revír několikrát změnil držitele, aniž by však bylo zahájeno dobývání. ${ }^{3}$

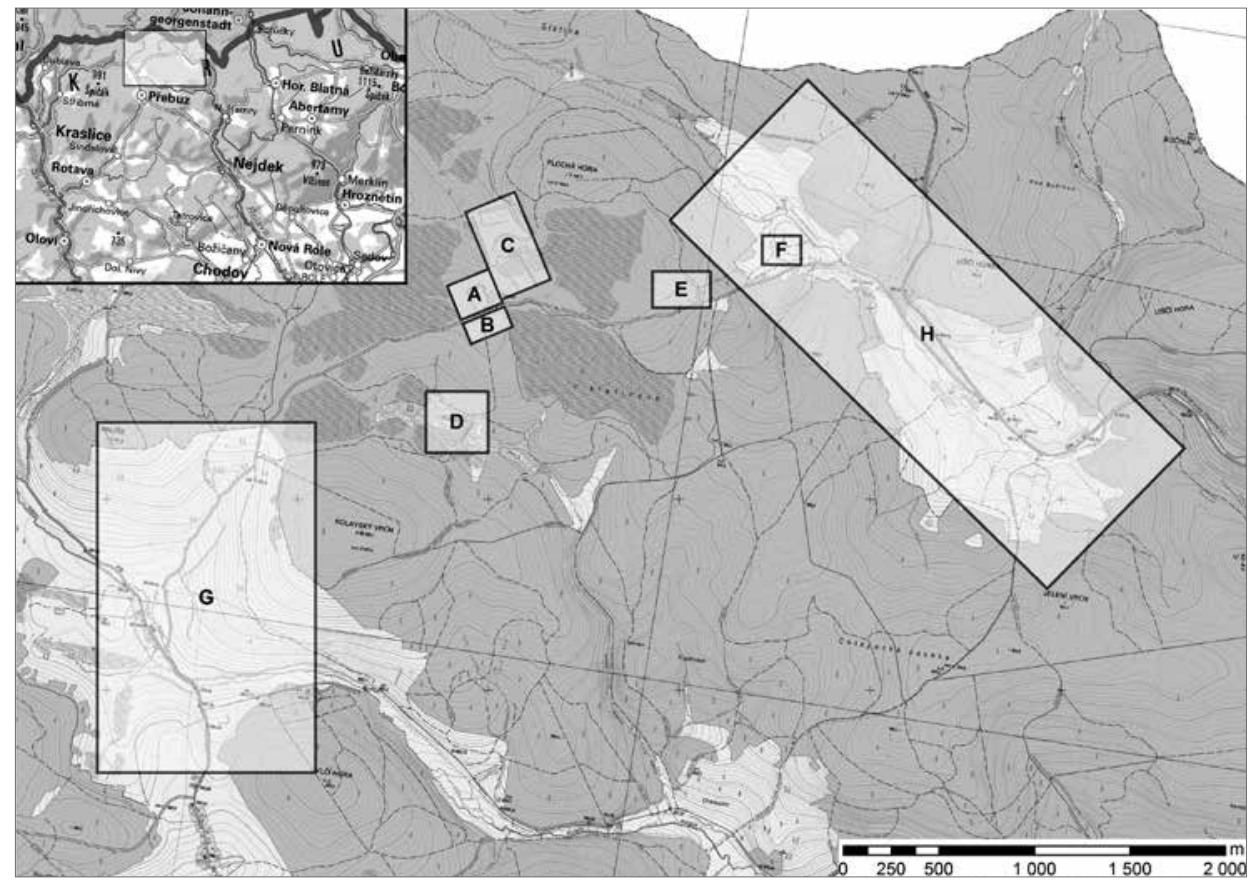

Obr. 1. Celkový plán lokality a okolí. A - důlní závod (jáma 1); B - zajatecký tábor; C - deponie hlušiny a odkaliště; D - vodní nádrž; E - jáma 2; F - ústí štoly sv. Jiří; G - zaniklá obec Rolava; H - zaniklá obec Jelení. Mapa D. Novák, J. Hasil.

Abb. 1. Gesamtplan der Fundstelle und Umgebung. A - Bergbaubetrieb (Grube 1); B - Gefangenenlager; C - Bergehalde und Klärteich; D - Stausee; E - Grube 2; F - Mündung des Georgstollens; G - Dorfwüstung Sauersack; H - Dorfwüstung Hirschenstand. Karte D. Novák, J. Hasil.

2 Terénní průzkum probíhá v rámci programu NAKI „Archeologická mapa ČR. Systém pro sběr, správu a prezentaci dat“, identifikační kód DF12P01OVV003; výsledky budou prezentovány mj. v rámci reprezentativního atlasu významných terénních lokalit v Čechách - Kuna a kol. $2014,324-328$.

3 Starší vývoj rudného hornictví v oblasti Rolavy a jejího bezprostředního okolí není doposud uceleně zpracován. Založení štoly sv. Jiří (odvodňuje jámy 1 a 2) je zmiňováno již k roku 1727 (Weber 2001, 2). Základní přehled podává P. Rojík (2000; 2005), který rovněž zpracoval přehled geologických poměrů širšího okoli lokality (2010). Materiály k počátkům moderní těžby jsou uloženy v archivním fondu závodu (SOA P, kart. 1). Z hlediska archeologie je třeba upozornit na četné povrchové doklady starši těžby na katastru obce, které doposud nebyly zdokumentovány a vyhodnoceny. 
Vypuknutí druhé světové války a výrazné omezení možností dovozu rudy či surového cínu obrátilo znovu pozornost plánovačů válečného hospodářství k rolavským ložiskům. Od roku 1940 tu začal vyrůstat komplex hlubinného dolu a pracovního tábora pro francouzské, později především sovětské válečné zajatce, ale i nuceně pracující jiných národností, na jejichž nedobrovolnou dřinu důl od počátku spoléhal. Později, v roce 1942, přibyla i úpravna rudy s nezbytnými skladovacími a odkalovacími zařízeními.

Těžba byla na dole Sauersack zahájena 1. srpna 1942 (SOA P, kart. 8), ${ }^{4}$ avšak již od počátku nedosahovala předpokládaných výnosů. Původní předpoklad, že práci zde zastanou zejména nedobrovolní pracovníci z řad válečných zajatců, se ukázal jako lichý, takže nezbylo než předisponovat na krušnohorský závod jednak kvalifikované pracovníky německé národnosti, jednak totálně nasazené Čechy, kteří pracovali zejména jako povrchoví pracovníci, tj. různí řemeslníci zajišt'ující údržbu areálu a jeho vybavení (SOA P, Kvalifikační karty zaměstnanců, kart. 2). Počty pracovníků byly poměrně kolísavé, dosahovaly však řádově $500-600$ zajatců, ${ }^{5}$ 200 pracovníků německé národnosti a několik desítek Čechů. ${ }^{6}$ Blížící se západní fronta však donutila německou armádu většinu zajatců odvést $\mathrm{k}$ jinému pracovnímu využití. Stalo se tak 29. dubna 1945 (SOA P, kart. 3), což byl mimochodem den, kdy americká vojska osvobodila zhruba 60 km vzdálený Cheb. Sedmého června 1945 opustilo závod 185 německých dělníků a horníků. Těžební i úpravnická činnost závodu Sauersack se tak úplně zastavila a osazenstvo dolu bylo zredukováno na 37 zaměstnanců, kteří prováděli udržovací práce.

\subsection{Důl Sauersack v poválečném období}

Dne 15. června 1945 převzal vedení závodu prozatímní národní správce Vojtěch Nedvěd (SOA P, kart. 9), který je s poválečným děním na dole Sauersack bytostně spojen a mimo jiné se zasloužil i o záchranu většiny archivních materiálů, jež dnes máme k dispozici. Pod jeho vedením zaměstnanci zahájili inventuru skladišt' a udržovací práce, prováděli však i sekání luk, odstraňování konstrukcí souvisejících s protileteckou ochranou, odstraňování německých nápisů a tabulek, došlo k obnovení meteorologické stanice a opravě telefonního spojení (SOA P, kart. 10). Složitou situaci prvních poválečných měsíců však komplikovaly okolnosti spojené s odsunem sudetských Němců a poválečným běsněním v česko-saském pohraničí - hned první den po nástupu nového správce přišel závod o dalších devět odsunutých zaměstnanců německé národnosti a několik budov v nedalekém Nejdku patřící závodu bylo vyrabováno (SOA P, kart. 7). Vlastní důl a úpravna byly podle situační zprávy národního správce z 28. června znovu připraveny k plnému provozu (SOA P, kart. 8), k jehož zahájení chyběly dva základní předpoklady - pracovní síla a finance na udržovací práce a náběh produkce.

$\mathrm{V}$ červenci počet zaměstnanců stoupl na 45 dělníků (SOA P, kart. 3). Kvůli odsunům německého obyvatelstva však více než polovina musela do konce roku opustit nejen závod, ale i Československo. V srpnu 1945 pracovalo na udržovacích pracích pouze 39 lidí, v září 1945 již jen 28 a od ř́ijna až do konce roku zde bylo zaměstnáno 22 vesměs německých dělníků (SOA P, Pracovní výkazy podle směn 1945-1947, kart. 7). Vedení závodu se snažilo ztrátám zaměstnanců bránit a vydávalo pro ně celou řadu potvrzení, která je měla uchránit před odsunem. Sedmého záři 1945 bylo např́iklad 22 horníků a povrchových pracovníků prohlášeno za specialisty. Šlo zejména o dělníky, kteří na dole pracovali již za války a kteří byli pro znovuobnovení prací naprosto nepostradatelní (SOA P, kart. 2). Zbytek dělníků byl většinou prohlášen za antifašisty, anebo byl jako důvod pro jejich vyřazení z odsunu uváděn sňatek s českou manželkou. V krajním př́ípadě, pokud zde nebyly žádné jiné okolnosti, bývalo alespoň př́ipomínáno, že nikdy veřejně nevystupovali jako podporovatelé nacistického režimu (SOA P, kart. 7). Často však ani to nezaručovalo, že dělník zůstane zaměstnán v závodu Sauersack. Někteří dělníci pocházeli

4 V literatuře se často pracuje také s jinými údaji (např. 27. 2. 1940; Weber 2001, 2), avšak archivní prameny je spolehlivě vyvrací.

5 Mezi zajatci pracovního komanda č. 7083 byli především Rusové a Francouzi, spolu s Řeky, Ukrajinci a Poláky. Z nich pobyt v táboře podle dosavadních zpráv nepřežilo 5 Rusů (2 při nehodě, 3 zastřeleni). Dozorci patřili ke strážnímu oddílu 1/827 Chodov (Weber 2001, 6). 6 Např. v březnu 1945 zde podle situační zprávy národního správce Vojtěcha Nedvěda z 28. června 1945 pracovalo 500 dělníků (SOA P, kart. 8); P. Rojík (2000, tab. na s. 100) uvádí maximální stav 553 dělníků. 
z rodin, jejichž větší část již odsunuta byla, a proto sami měli motivaci Československo opustit. Specializovaní dělníci a horníci museli být proto často nahrazováni nově zaškolenými pracovníky, převážně lesními dělníky (SOA P, kart. 7). Za celou tuto dobu není znám prrípad, že by v závodu pracoval jiný Čech než prozatímní národní správce V. Nedvěd.

Druhým největším problémem, se kterým se musel důlní závod potýkat, byl nedostatek finančních prostředkủ. Národní správa dolu se musela vyrovnávat s celou řadou dřívějších pohledávek, ke kterým byla zavázána $\mathrm{z}$ válečných dob. Pokud šlo o německé firmy, byly závazky zrušeny československou vládou. Ostatní věřitelé, tedy firmy, které přešly do národní správy, či prrímo české podniky, byli informováni o tom, že důlní závod dosud není v provozu a že vedení závodu nemůže př́slušné platby provést (SOA P, kart. 7). Největšími položkami v nákladech závodu byly mzdy, elektřina a pohonné hmoty. Vzhledem k tomu, že o osudu celého dolu nebylo dosud rozhodnuto a že neprobíhaly žádné těžební práce, nezískával závod finanční prostředky, kterými by mohl tyto pohledávky v plné šíři krýt. Brzy byla vyčerpána již i tak nevelká hotovost, která závodu zbyla z dřívějších let, a závod se ocitl v insolvenci. Situaci ilustruje konvolut korespondence, ve které Vojtěch Nedvěd sděluje nejrůznějším firmám, že závod dosud není $\mathrm{v}$ provozu, nemá dostatečné množství prostředků k provedení plateb, a prosí tyto firmy o trpělivost (SOA P, kart. 7). Tato krizová situace vyvrcholila v listopadu 1945, kdy nebylo možné pokrýt ani výplaty zaměstnanců.

Jak bylo již řečeno, na dole Sauersack nebyly zastaveny pouze důlní práce, ale i veškerá úpravnická činnost. Tím pádem firma disponovala značným množstvím nezpracované rudniny v závodních skladech. Vedení závodu se proto rozhodlo, že tyto zásoby zpeněží. K tomuto kroku se národní správce Nedvěd odhodlal zejména po 15. listopadu 1945, kdy cena cínu vzrostla o 155 \% (SOA P, kart. 7). Prodej probíhal většinou tak, že do neprŕíliš vzdáleného úpravnického závodu byl po předchozí dohodě zaslán vzorek, přičemž posléze, pokud konkrétní úpravna projevila zájem, bylo posláno i větší množství (SOA P, kart. 7). Jak však vyplývá z následné korespondence, řada úpraven nebyla s kvalitou rudniny spokojena a např́íklad závod Kovová hut' Velvary se 14. prosince obrátil př́ímo na V. Nedvěda s tím, že materiál se zpracovává velice špatně, a žádá vysvětlení, jakými technologickými postupy byla rudnina dříve zpracovávána v saském Freibergu, kam část rolavské produkce směřovala za války (SOA P, kart. 7). Další možností řešení nepříznivé finanční situace, která se naskýtala, byla vedlejší ekonomická činnost, konkrétně pronajmutí sklepních prostor (SOA P, kart. 7) a prodej sena z přilehlých luk patřících závodu. Avšak ani tak se nepodařilo náklady udržovacích prací finančně krýt. Do nového roku 1946 proto cínový důl Sauersack nevstupoval s nejlepšími vyhlídkami.

V lednu roku 1946 se celá situace vystupňovala natolik, že se Vojtěch Nedvěd obrátil s žádostí o úvěr na peněžní ústavy v nejdeckém a karlovarském okrese, které však závodu žádný provozní kapitál neposkytly. Národní správce Nedvěd se proto také obrátil na Československý reeskontní a lombardní ústav v Praze, ale i ten žádost zamítl (SOA P, kart. 8). Situace se stala tak vážnou, že v hlášení z 22. ledna 1946 (SOA P, kart. 8) prozatímní správce upozorňuje své nadřízené, že již není možné z finančních a personálních důvodů provádět na dole Sauersack žádné další udržovací práce.

Během května a června zároveň došlo $\mathrm{k}$ další významné vlně transferů německého obyvatelstva. Z dubnových 29 zaměstnanců zbylo v závodu v červnu 1946 pouhých 11 dělníků (SOA $P$, Hlášení o osazenstvu a těžbě 1945-1947, kart. 2). Všichni tito zaměstnanci byli zapracovanými dělníky a pracovali především jako specializovaní pumpaři, takže právě jako specialisté byli na žádost národního správce z odsunu vyňati. Devět z nich se však dobrovolně přihlásilo k poslední vlně odsunu, která byla plánována na 10. srpna 1946. Prozatímní národní správce dolu Sauersack ve svém dopise z 24. července vyslovil obavu, že pokud nebude umožněno těmto horníkům zařadit se do odsunu, pokusí se Československo opustit sami, což vzhledem k tomu, že závod byl umístěn zhruba 10 minut chůze od státní hranice, nebyl žádný problém (SOA P, kart. 8). Negativní vliv těchto okolností na práce $\mathrm{v}$ závodě (tehdy již probíhala konzervace a demontáž v budoucnu upotřebitelného zařízení) dobře dokládají další žádosti vedení závodu z 20. června 1946 o opětovné uvolnění skupiny pumpařů z odsunu (SOA P, kart. 7). Kromě problému s ne- 
dostatkem zaměstnanců přetrvával v polovině roku 1946 i problém finanční, a to zejména z toho důvodu, že platby za odprodané vybavení a cínový koncentrát nepřicházely dostatečně rychle, což se dá doložit na dopisu V. Nedvěda ze 4. června 1946 (SOA P, kart. 8), ve kterém žádal urychlení platby za dodaný materiál, nebot' závod opět nebyl schopen vyplácet dělníkům mzdy. V té době však již práce nesměřovaly $\mathrm{k}$ udržení závodu v provozuschopném stavu, nebot' Ústřední ředitelství československých dolů rozhodlo již počátkem února 1946 celý důlní a úpravnický závod Sauersack uzavřít, strojní a jiné vybavení odvézt do jiných závodů a obě jámy překrýt betonovou zátkou.

Do konce roku 1946 byl prováděn na dole Sauersack pouze dohled nad odvozem všech strojů a materiálu a 1. ledna 1947 také skončila úloha prozatímního národního správce Vojtěcha Nedvěda, který odešel k nedalekému národnímu podniku Přebuz (SOA P, kart. 9). Dne 17. března 1947 pak ztratil závod i „své jméno“, nebot' k tomuto datu došlo k úřednímu přejmenování obce Sauersack na obec Rolava, což se odrazilo mj. i ve spisové pozůstalosti závodu (označení archivního fondu jako Cínové doly Rolava). ${ }^{7} \mathrm{~V}$ této době však již závod přestal být živoucím organismem a začal se přeměňovat $\mathrm{v}$ archeologickou lokalitu.

\section{Archeologizace areálu}

\subsection{Verspektivě písemné evidence}

Dne 25. února 1946, kdy byla situace dolu již kritická, obdržel V. Nedvěd telegram odeslaný Ústředním ředitelstvím československých dolů, který vyřkl stručný a zřejmý ortel nad důlním závodem Sauersack: „Začněte ihned s demontáží v dolech“(SOA P, kart. 8). Již 26. února pak byla zahájena demontáž na jámě 1 (v areálu závodu; obr. 1:A) v $60 \mathrm{~m}$ a na jámě 2 (obr. 1:E) na patře ve $180 \mathrm{~m}$. Pátého května 1946 proběhl první doložitelný odvoz materiálu a strojního zařízení z dolu Sauersack, a to do závodu v Netolicích (SOA P, kart. 9). „,V letech 1946-1947 bylo důlni zařizení demontováno a instalováno do jiných závodì, jmenovitě Tuchlovice u Kladna, Tisová u Kraslic, Krásno a Přebuz (svědectví zaměstnanců, správců přislušných dolů i dopravců)“ (Rojík 2000, 101).

Dne 29. května 1946 však došlo k překvapivému zvratu. Ačkoliv demontážní práce na jámě č. 2 byly provedeny na obzorech 180, 120 a 90 m, dostal Vojtěch Nedvěd příkaz vrchního rady Jáchymovských rudných dolů Ing. Hegnera, aby tato patra nadále udržoval, tzn. nadále z nich čerpal důlní vodu. Národní správce dolu Sauersack na tento překvapivý př́íkaz reagoval dotazem na vedení Jáchymovských rudných doli̊, zda má tato patra skutečně udržovat, a mj. připomínal, že čerpání důlní vody stojí 50000 Kčs měsíčně (SOA P, kart. 7). Krátce nato bylo definitivně rozhodnuto o celkové demontáži a o odvozu materiálu a strojního zařízení.

Dne 15. srpna 1946 byl vedení závodu písemně potvrzen telefonát z téhož dne, ve kterém bylo národním podnikem Př́ibramské rudné doly rozšiřeno nařízení o demontáži i o zastavení čerpání důlní vody na obou jamách v dole Sauersack (SOA P, kart. 9). O částečném splnění tohoto př́íkazu informoval V. Nedvěd 22. srpna 1945 Báňský revírní úřad v Karlových Varech, konkrétně ohlásil ukončení demontážních prací na obou jamách a fakt, že již 14. srpna byla vytažena veškerá čerpadla na jámě 2 . Ukončení čerpání důlní vody na jámě 1 bylo naplánováno na 30. srpna (SOA P, kart. 8). Na základě těchto zpráv bylo Příbramskými rudnými doly následně naplánováno úplné uzavření dolu Sauersack, a to na 2. září 1946 (SOA P, kart. 8). Demontáž na všech patrech obou jam byla provedena již 23. srpna. Kolejnice, potrubí, lutny (slouží k odvětrávání dolu) a jiný vytažený materiál byl uskladněn a nejhlubší patra byla vzápětí zatopena. Klece byly vyndány a umístěny do šachetní budovy. Toho dne Jáchymovské doly také začaly pomocí vlastních dělníků odvážet materiál a zařízení (SOA P, kart. 2). V této době vlastnil závod Sauersack ještě pět obyvatelných obytných domů (SOA P, kart. 9), přičemž dva se nacházely přímo

\footnotetext{
7 SOA P, kart. 9. Obec Rolava měla na počátku 20. let 20. století 1162 obyvatel, kteří nacházeli obživu zejména v rudném hornictví a souvisejících provozech (Pfohl 1922, 495). Dějiny horské vsi, která s výjimkou několika stavení fyzicky zanikla v 50. letech a dnes již nepředstavuje samosprávnou jednotku (spadá pod obec Přebuz), přibližuje vlastivědná publikace W. Laubera (2004).
} 
v areálu závodu (objekty 37 a 35), dva v obci Jelení (čp. 177 a 29) a jeden v Nových Hamrech (čp. 357). Již zmíněný dodatek k provozní zprávě také dále uvádí, že 2. záŕí 1946 byly veškeré důlní prostory zatopeny a že voda přetéká přes ohlubně dolu (SOA P, kart. 2).

Poslední fáze demontáží v areálu důlního závodu proběhla v létě roku 1947, kdy pracovníci Jáchymovských rudných dolů mj. demontovali těžní věž na jámě 2 (9. července) a později zabetonovali obě rolavské důlní jámy (SOA P, kart. 8).

Do gesce prozatímního národního správce závodu Sauersack spadal i přilehlý zajatecký tábor, od roku 1945 neužívaný. V. Nedvěd navštívil 19. října 1945 zástupce ředitele Státních drah v Plzni, aby projednal možnost odkoupení tehdy již nevyužívaných dřevěných domků, které dříve sloužily k ubytování válečných zajatců (SOA P, kart. 7). Šlo o dvanáct budov, k jejichž okamžitému prodeji ovšem nedošlo, protože stále ještě nebyla známa budoucnost cínového dolu Sauersack. Vojtěch Nedvěd tuto skutečnost ředitelství Státních drah osvětlil v dopise z 10. listopadu 1945 (SOA P, kart. 7). Oznámil zároveň, že pokud bude rozhodnuto o uzavření důlního závodu, bude velice rád, pokud budou budovy odprodány. Jelikož se finanční situace závodu do jeho zrušení nezlepšila a na dole nebylo nutné ubytovávat ani větší počet dělníků, je možné se domnívat, že baráky později odprodány byly a jejich odvoz pro potřeby Státních drah byl po rozhodnutí ukončit veškerou činnost důlního závodu (patrně někdy na jaře 1946) proveden.

\subsection{V perspektivě archeologické evidence}

Prezentované závěry vychází z povrchového průzkumu provedeného v letech 2013 a 2014. Jádro lokality lze rozdělit na:

a) areál důlního a zpracovatelského závodu (obr. 1:A),

b) areál zajateckého tábora (obr. 1:B),

c) areál s haldami deponie vytěžené hlušiny a odkalištěm (obr. 1:C),

d) a přehradu sloužící $\mathrm{k}$ zásobování areálu vodou (obr. 1:D).

Rámcově byla rekognoskována celá plocha těžebního komplexu, avšak hlavní pozornost byla věnována reliktům zajateckého tábora, který tvoří samostatně vymezenou část jižně od silnice procházející mezi táborem a důlním závodem (obr. 2). Tábor dodnes spíše unikal pozornosti, jelikož zdejší podstatně více archeologizované situace zastiňuje přítomnost dobře dochovaných budov úpravny a dostupné archivní prameny se soustřed'ují spíše na vlastní závod než na přidružený tábor. Jeho poznání tak dosud nedosahovalo ani základní úrovně a jedním z cílů provedeného průzkumu bylo vyrovnání tohoto nepoměru.

Objekty tábora byly dokumentovány za využití dvojpřijímačové duální aparatury GPS (typu Topcon HiPer+), laserového dálkoměru a fotodokumentace. Dále byly provedeny prostorové korekce na základě historických leteckých snímků (HISTORICKÉ ORTOFOTO; obr. 3), archivní plánové dokumentace (SOA P, kart. 11) a snímků leteckého laserového skenování (zdroj: ČÚZK). Pozornost byla věnována zejména stavu dochování reliktů, typům užitých konstrukcí a základnímu metrickému popisu. Sledovány byly také další specifické znaky jednotlivých staveb (otopné zařízení, podsklepení, jímky, napojení na vodovod apod.). Areál tábora byl prozkoumán systematicky a lze předpokládat, že byla odhalena většina dochovaných reliktů. Naopak $\mathrm{v}$ prostoru dolu byla provedena pouze revize stávajícího stavu, při které mohlo být konstatováno, že s výjimkou několika objektů (zřejmě později vybudovaných) terénní situace odpovídá dochované stavební dokumentaci (SOA P, kart. 11), resp. již publikovaným plánkům areálu (Rojík $2000,105)$. Detailní průzkum a dokumentace zde budou provedeny později se zřetelem k připravované kampani, která by měla na základě hmotného svědectví přiblížit podobu a rozmístění úpravnické technologie, nebot' strojní vybavení závodu Sauersack není uceleně postiženo písemnými prameny. 


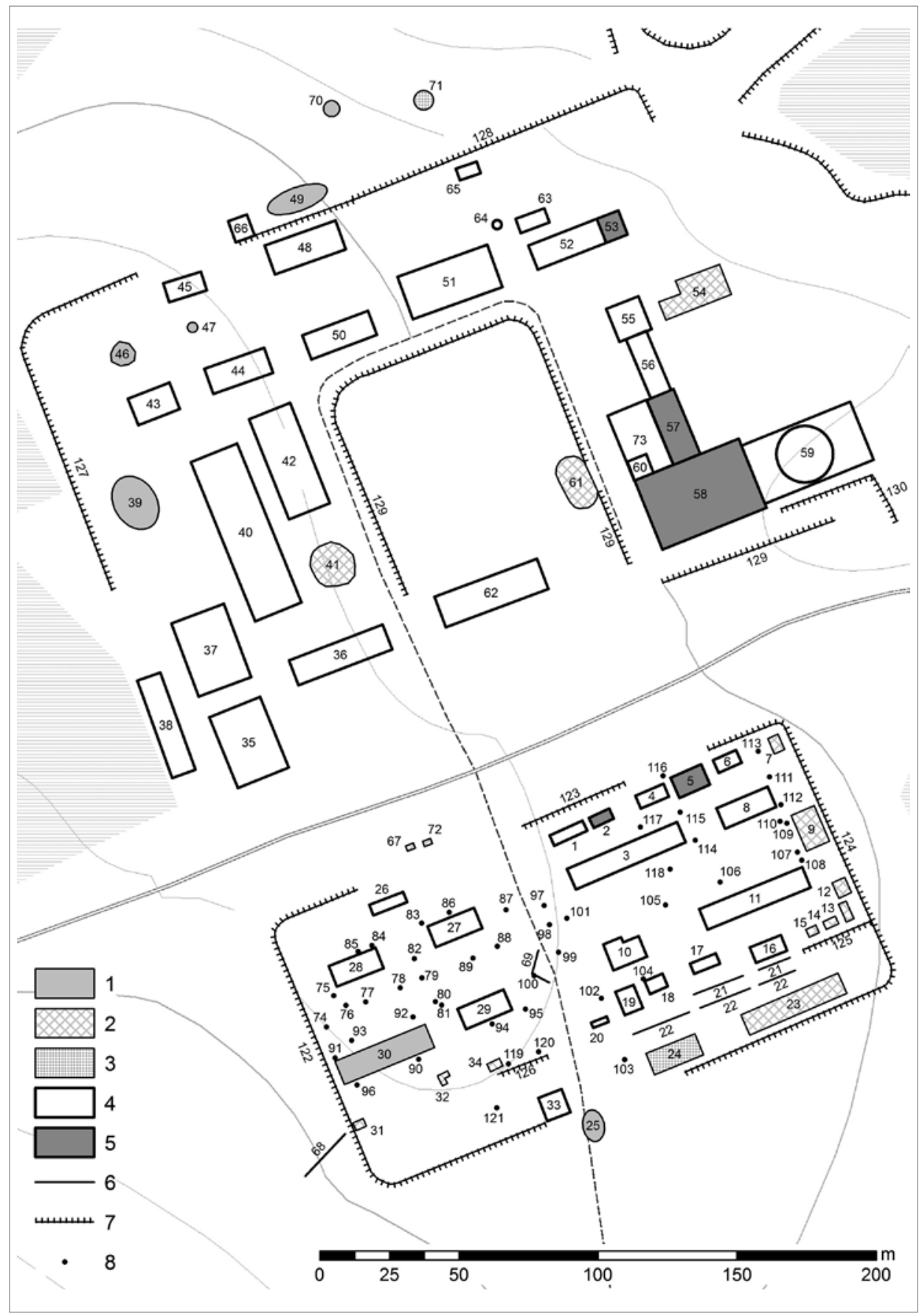

Obr. 2. Plán tábora a přilehlého důlního závodu s označením jednotlivých objektů. 1 - konkávní objekty; 2 - konvexní objekty; 3 - rovné plochy (zrcadla); 4 - ruiny; 5 - zastřešená torza staveb; 6 - konkávní linie; 7 - terénní stupně; 8 - bodové objekty (sledováno pouze v prostoru zajateckého tábora). Zaměření a plán D. Novák, J. Hasil.

Abb. 2. Planskizze des Lagers und des angrenzenden Bergwerkbetriebs mit Kennzeichnung der einzelnen Objekte. 1 - konkave Objekte; 2 - konvexe Objekte; 3 - ebene Flächen (Spiegel); 4 - Ruinen; 5 - überdachte Gebäudetorsi; 6 - konkave Linien; 7 - Geländestufen; 8 - punktuelle Objekte (nur im Bereich des Gefangenenlagers beobachtet). Vermessung und Planskizze D. Novák, J. Hasil. 


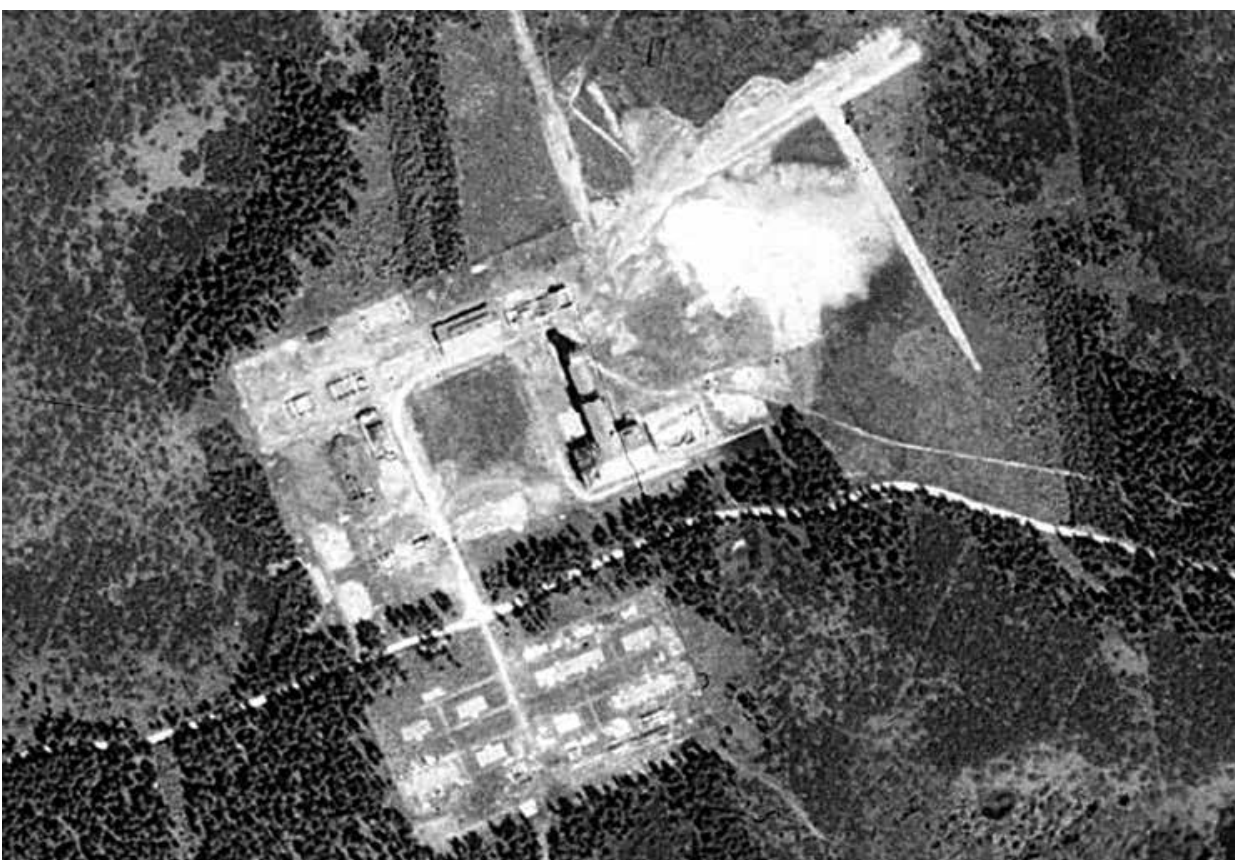

Obr. 3. Historický letecký snímek lokality těsně po zániku areálu. Zdroj HISTORICKÉ ORTOFOTO.

Abb. 3. Historische Luftaufnahme der Fundstelle gleich nach dem Untergang des Areals. Quelle HISTORISCHES ORTHOFOTO.

\subsection{Katalog objektů}

Katalog je řazen podle čísel objektů bez ohledu na jejich polohu. Deskripce se skládá z rozměrů (délka $\times$ šířka), slovního popisu a předběžné interpretace. Rozměry jsou vzhledem k výpovědním možnostem měření zaokrouhleny s přesností na $0,5 \mathrm{~m}$. Jednotlivé popisy vychází z terénní situace. Přítomnost otopného zařízení indikují cihlové ruiny kamen a komínů, vodovodní přípojky připomínají nad povrch vystupující litinové trubky, přípojky kanalizace pak naznačují ústí kameninových potrubí. Ačkoliv je zde rámcově popsána celá lokalita, pozornost je věnována zejména areálu lágru pro nuceně pracující. Vlastní těžební a úpravnický závod je popsán na základě originální dokumentace, starší literatury a povšechné prospekce. Detailní analýza tohoto areálu je ve stadiu přípravy a bude předložena v příštích letech.

\section{Objekt 1}

Rozměry: $13 \times 4 \mathrm{~m}$

Popis: Nízký nevýrazný konvexní obdélný objekt s destrukcí cihlového otopného zařízení bez stop podezdívky či dalších konstrukcí, členěný na min. tři prostory.

Interpretace: Podle plánu areálu z 2. června 1942 (SOA P, kart. 11) jde o sklad dřeva a prádelnu.

\section{Objekt 2}

Rozměry: $8 \times 4,5 \mathrm{~m}$

Popis: Drnem překrytý klenutý sklep se zastřešeným schodištovým přístavkem se vstupní šijí. Pravděpodobně dochován v původním stavu bez výrazných změn. Sklep je zaklenut valenou betonovou klenbou s malým větracím otvorem. Stěny jsou nabíleny a pokryty nápisy nejasného stáří, včetně nápisů v azbuce. Podlaha je hliněná.

Interpretace: Podle plánu areálu z 2. června 1942 (SOA P, kart. 11) jde o uhelný sklep. 


\section{Objekt 3}

Rozměry: $43 \times 8 \mathrm{~m}$

Popis: Objekt sestávající z betonové podezdívky na půdorysu obdélníka. Dům je tvořen dvěma celky - podsklepeným prostorem členěným na menší místnosti (13 metrů) a větší východní částí bez zřejmého dělení $(30 \mathrm{~m})$. Sklep je vybaven okenními otvory, do domu vede vodovodní trubka, byl vybaven mohutným komínem (dnes destruován; obr. 5:B) a jímkou vně objektu. Do objektu vedly dvě vně vysazená vstupní schodiště.

Interpretace: Podle plánu areálu z 2. června 1942 (SOA P, kart. 11) jde o dvouúčelovou budovu; západní (podsklepená) část sloužila jako kuchyně a jídelna, východní jako ubytovací objekt (,Schlafbaracke“).

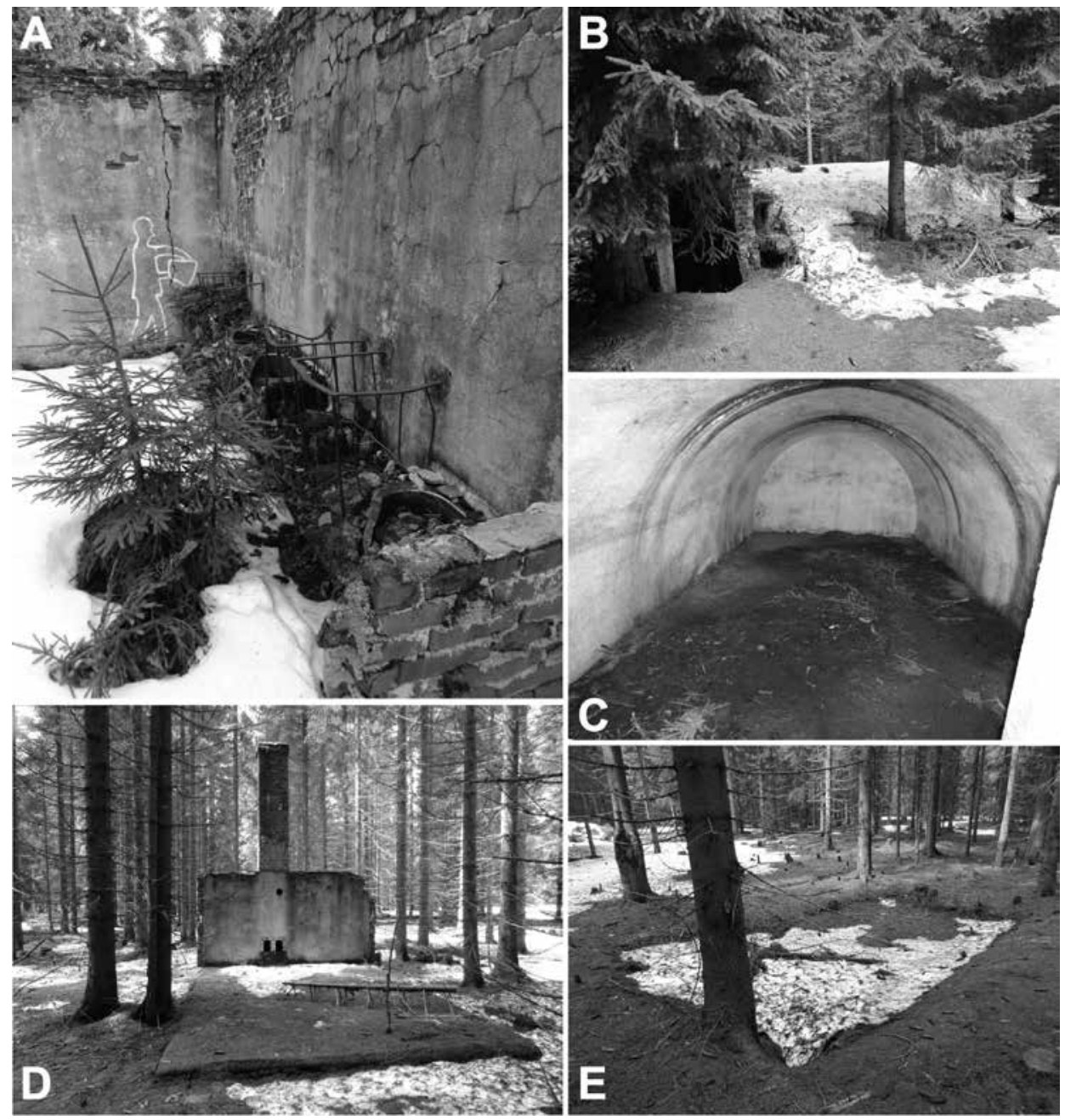

Obr. 4. Výběr fotografií objektů. A - vrátnice s garážemi a stájí (obj. 36); B - vězeňská cela z exteriéru (obj. 5); C - interiér vězeňské cely (obj. 5); D - ruina skladovacího objektu 17; E - relikt strážního domku (obj. 7). Foto J. Hasil, 2013-2014.

Abb. 4. Auswahl an Fotos der Objekte. A - Pforte mit Garagen und Stall (Obj. 36); B - Gefängniszelle Außenansicht (Obj. 5); C - Gefängniszelle (Obj. 5); D - Ruine eines Lagerobjekts 17; E - Relikt eines Aufseherhauses (Obj. 7). Fotos J. Hasil, $2013-2014$. 


\section{Objekt 4}

Rozměry: $11 \times 4,5 \mathrm{~m}$

Popis: Konvexní mírně vyvýšený obdélný objekt s destrukcí cihlového otopného zařízení, vybavený přisazenou jímkou.

Interpretace: Na plánu areálu z 2. června 1942 (SOA P, kart. 11) se má v prostoru tohoto objektu nacházet dvouúčelový objekt (nyní obj. 4 a 5); západní část měla sloužit jako kuchyně. Je možné, že došlo k modifikaci stavebního záměru, nebot' obj. 4 má výrazně odlišné rozměry.

\section{Objekt 5}

Rozměry: $12 \times 7,5 \mathrm{~m}$

Popis: Typově odpovídá objektu 2. Stěny jsou však čistě bílé, bez nápisů a obsahuje dva větrací otvory (obr. 4:B, C).

Interpretace: Na plánu areálu z 2. června 1942 (SOA P, kart. 11) se má v prostoru tohoto objektu nacházet dvouúčelový objekt (nyní obj. 4 a 5); jeho východní část je označena zkratkou „Gef.“ (snad „Gefängnis“, tj. věznice). Je možné, že došlo k modifikaci stavebního záměru, nebot' obj. 5 má výrazně odlišné rozměry.

\section{Objekt 6}

Rozměry: $8,5 \times 5 \mathrm{~m}$

Popis: Vyrovnaná plošina tvořená betonovou deskou překrývající podzemní prostor, zpřístupněný čtvercovým průlezem se zárubní pro poklop. V okolí větší množství volně ležících artefaktů. Interpretace: Podle plánu areálu z 2. června 1942 (SOA P, kart. 11) jde o budovu toalet.

\section{Objekt 7}

Rozměry: $6,5 \times 4 \mathrm{~m}$

Popis: Pravidelně obdélný mírně zahloubený objekt v nároží tábora bez zřetelných dalších struktur (obr. 4:E).

Interpretace: Na plánu areálu z 2. června 1942 (SOA P, kart. 11) se v tomto prostoru má nacházet stanoviště strážných.

\section{Objekt 8}

Rozměry: $20 \times 8 \mathrm{~m}$

Popis: Objekt tvořený obdélnou betonovou podezdívkou, zpř́istupněný dvojicí vně vysazených schodišt' s připojením na vodovod.

Interpretace: Ubytovací objekt (,Schlafbaracke“).

\section{Objekt 9}

Rozměry: $14 \times 9 \mathrm{~m}$

Popis: Obdélný konkávní objekt zahlubující se o ca $0,5 \mathrm{~m}$, se zbytky cihlového komína v centrální části stavby. Připojení na vodovod (obr. 6:C).

Interpretace: Ubytovací objekt (,Schlafbaracke“).

\section{Objekt 10}

Rozměry: $13,5 \times 10 \mathrm{~m}$

Popis: Objekt úhlové dispozice je tvořen obdélnou částí $8 \times 13,5 \mathrm{~m}$ a menším výběžkem v severozápadním rohu s rozměry $2 \times 5,5 \mathrm{~m}$. V západní části se nachází sklep a je zde patrné vnitřní členění budovy. $Z$ jihu je přisazena jímka. Př́stup byl realizován severojižním směrem po schodišti přisazeném od východu ke zmiňovanému přístavku. Základ tvoří betonová deska.

Interpretace: Podle plánu areálu z 2. června 1942 (SOA P, kart. 11) jde o umývárnu. 

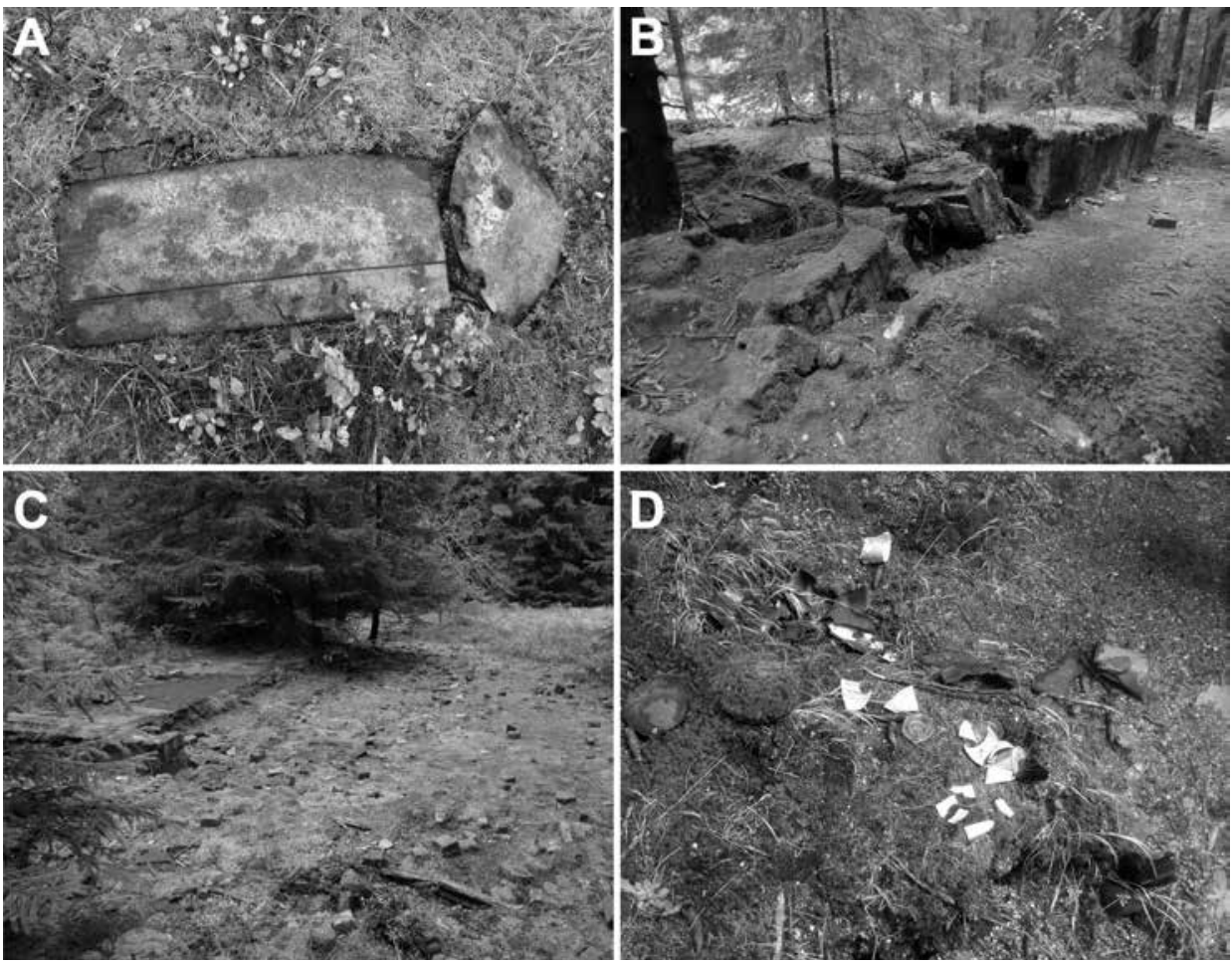

Obr. 5. Detaily archeologizovaných situací. A - pozůstatek plechového komínku (obj. 11); B - destrukce kuchyňského komína (obj. 3); C - destrukce cihlové stěny (obj. 51); D - odpadní areál (obj. 25). Foto J. Hasil, 2013-2014.

Abb. 5. Details der archäologisierten Situationen. A - Überrest eines Schornsteinaufsatzes aus Blech (Obj. 11); B - zerstörter Küchenschornstein (Obj. 3); C - zerstörte Backsteinwand (Obj. 51); D - Müllareal (Obj. 25). Fotos J. Hasil. $2013-2014$.

\section{Objekt 11}

Rozměry: $40 \times 8 \mathrm{~m}$

Popis: Obdélná budova s betonovou podezdívkou a vně vysazenými schodišti bez zřejmých konstrukcí. Na povrchu nalezena část plechové komínové roury se stříškou (obr. 5:A).

Interpretace: Ubytovací objekt („Schlafbaracke“).

\section{Objekt 12}

Rozměry: $6 \times 5,5 \mathrm{~m}$

Popis: Přibližně $0,5-1 \mathrm{~m}$ zahloubený obdélný objekt s početnými artefakty na povrchu.

Interpretace: Bez interpretace.

\section{Objekt 13}

Rozměry: $6,5 \times 2,5 \mathrm{~m}$

Popis: Výrazně protáhlý a značně zahloubený objekt bez stop konstrukcí s početnými artefakty. Interpretace: Podle plánu areálu z 2. června 1942 (SOA P, kart. 11) jde o toalety.

\section{Objekt 14}

Rozměry: $5 \times 3 \mathrm{~m}$

Popis: Obdélný konkávní objekt bez bližšího určení.

Interpretace: Bez interpretace. 


\section{Objekt 15}

Rozměry: $(3,5) \times 3 \mathrm{~m}$

Popis: Obdélný konkávní objekt bez bližšího určení; v delší ose je ukončení směrem k západu rozpité a nelze určit jeho skutečné rozměry.

Interpretace: Bez interpretace.

\section{Objekt 16}

Rozměry: $11,5 \times 6 \mathrm{~m}$

Popis: Ruina obdélného cihlového objektu s dvojicí mohutných komínů, jímkou a betonovou základovou deskou. Patrné je vnitřní členění budovy.

Interpretace: Podle archivních pramenů jde o odvšivovací stanici (SOA P, kart. 11).

\section{Objekt 17}

Rozměry: $10 \times 4 \mathrm{~m}$

Popis: Ruina stavby se stojícím komínem a cihlovou prříčkou, založená na obdélné betonové desce (obr. 4:D).

Interpretace: Podle plánu areálu z 2. června 1942 (SOA P, kart. 11) jde o budovu sloužící $\mathrm{k}$ uskladnění dřeva a uhlí. Vzhledem k jeho podobě však interpretace zůstává nejistá (mohlo dojít ke změně oproti původnímu záměru zobrazenému na plánu).

\section{Objekt 18}

Rozměry: $6 \times 4,5 \mathrm{~m}$

Popis: Zahloubený prostor překrytý betonovou deskou se dvěma ven vysazenými obdélnými otvory (ca $2 \times 1 \mathrm{~m})$ na kratších stranách stavby.

Interpretace: Budova latríny s jímkou.

\section{Objekt 19}

Rozměry: $9 \times 6,5 \mathrm{~m}$

Popis: Ruina dvojdílné obdélné stavby. Severní, patrně dřevěný díl je konstrukčně shodný s objektem 18. Jižní část stavby tvoří cihlová ruina se zachovalým okenním otvorem ve východní stěně a dveřním otvorem $\mathrm{v}$ západní stěně. Od dveří k oknu probíhá koridor, na který z jihu navazují čtyři úzké prostory dělené zděnými příčkami. Jižní stěna má zajímavou sendvičovou konstrukci pro zvýšení tepelného komfortu (obr. 6:B); nynější dutina mezi líci na šíři jedné cihly byla patrně vyplněna izolačním materiálem. Při západním líci zděné části leží velká jímka. Interpretace: Budova spojených latrín (severní část) a sprch (jižní část) s jímkou na splaškovou vodu.

\section{Objekt 20}

Rozměry: $6 \times 2 \mathrm{~m}$

Popis: Obdélná stavba je zachována téměř v původním stavu, chybí pouze pultová střecha, která objekt zakrývala. Vnitřní prostor nízké cihlové stavby (výška $0,9 \mathrm{~m}$ ) je rozdělen na tři stejně velké prostory zpř́ístupněné samostatnými vstupy od severu. Vstupy jsou opatřeny dvojicí jednoduchých pantů.

Interpretace: Účel není zřejmý, může však jít vzhledem k výšce stavby např. o kotce pro zvířata (psy?).

\section{Objekty 21-22}

Rozměry: $60 \times 3,5 \mathrm{~m}$

Popis: Dva paralelně běžící hluboké liniové výkopy s šikmými stěnami, lemované deponií vykopaného materiálu. Př́íkopy jsou na dvou místech na ca $2 \mathrm{~m}$ přerušeny. Severní z obou příkopů je již v západní části zasypán a jeho původní přítomnost indikuje mírná prosedlina. 
Interpretace: Výkopy pro položení trubek kanalizace. Přerušení indikují nutnost přechodu přes prostor stavby v jejím průběhu. Zasypaná část pravděpodobně již obsahuje položené zatrubnění. Výstavba tak musela probíhat těsně před koncem války a odchodem vězňủ.

\section{Objekt 23}

Rozměry: $39 \times 8,5 \mathrm{~m}$

Popis: Obdélný konkávní objekt s cihlovou vyzdívkou.

Interpretace: Obytná stavba.

\section{Objekt 24}

Rozměry: $(19) \times(7) \mathrm{m}$

Popis: Velmi špatně čitelný obdélný objekt indikovaný vyrovnanou plochou a drobnou hranou v jižní a západní části. Rozměry jsou neúplné.

Interpretace: Snad obytná stavba velmi lehké konstrukce (provizorní?).

\section{Objekt 25}

Rozměry: $10 \times 8 \mathrm{~m}$

Popis: Nepravidelná kupa s četnými narušeními, tvořená popelem a odpadem z doby existence tábora (obr. 5:D).

Interpretace: Odpadní areál. Jeho poloha na okraji tábora a profily narušení značí jeho zachování in situ, bez sekundárního přmemístění.

\section{Objekt 26}

Rozměry: $13 \times 4 \mathrm{~m}$

Popis: Mírně konvexní obdélná vyvýšenina s pozůstatky cihlového komína a s přiloženou jímkou.

Interpretace: Podle plánu areálu z 2. června 1942 (SOA P, kart. 11) jde o prádelnu.

\section{Objekty 27-29}

Rozměry: $17,5 \times 8 \mathrm{~m}$

Popis: Trojice konstrukčně i rozměrově shodných staveb. Základ tvoří obdélný betonový sokl, další pozůstatky nejsou patrné. Zpřístupněny jsou jedním schodištěm uprostřed delší stěny. Ke stavbám jsou přivedeny vodovodní př́ípojky a napojení kanalizace. Ty jsou společně vyvedeny v interiéru do manipulační šachty uprostřed delších stěn budov. V některých nárožích jsou zř̌jmé otvory po svodech okapové vody do kanalizace.

Interpretace: Podle plánu areálu z 2. června 1942 (SOA P, kart. 11) jde v případě obj. 27 o kancelářský objekt a v př́ípadě obj. 28 a 29 o obytnou stavbu („Wohnbaracke“ - srov. označení „Schlafbaracke“" pro ubytovací objekty ve východní části tábora).

\section{Objekt 30}

Rozměry: $34,5 \times 9 \mathrm{~m}$

Popis: Obdélný konvexní objekt s napojením na vodovod. Pozůstatky střešních tašek a litinových dvířek kamen.

Interpretace: Obytná stavba označená - i přes zcela odlišnou konstrukci v porovnání s obj. 28 či 29 - jako „Wohnbaracke“.

\section{Objekt 31}

Rozměry: $4 \times 2,5 \mathrm{~m}$

Popis: Konkávní obdélný ke středu se zahlubující objekt, přisazený těsně k terénní hraně ohraničující areál (obj. 122) v bodě, ve kterém začíná u paty meze strouha (obj. 68).

Interpretace: Pravděpodobně svod kanalizace s přepadem a vyústěním mimo hranice areálu. 

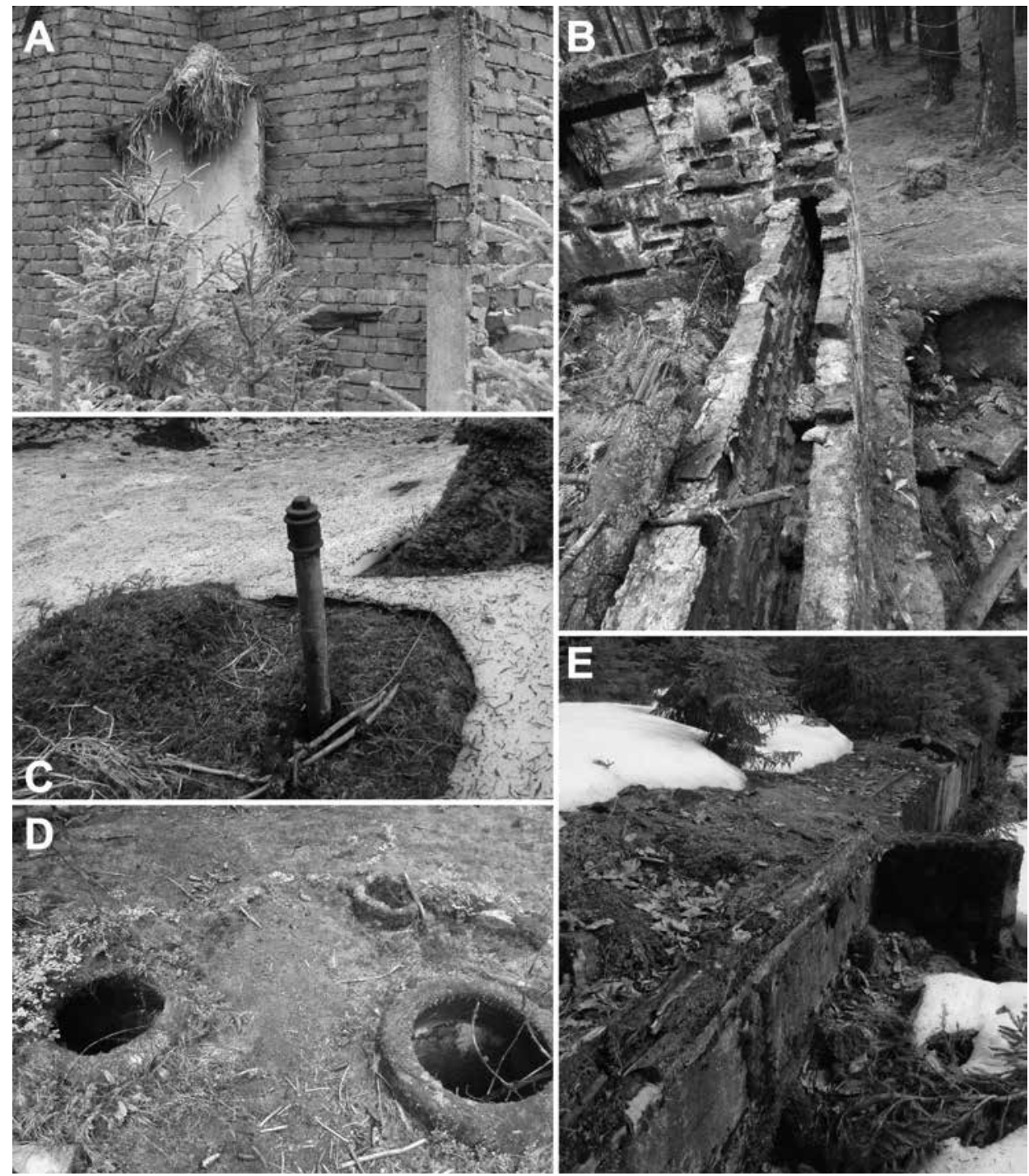

Obr. 6. Zachovalé technické detaily. A - zateplení stěn staveb (obj. 36); B - zdvojená zed' sprch (obj. 19); C - př́ipojka vodovodního potrubí (obj. 9); D - kanalizační šachty v nároží pochozí plochy (obj. 109; 110); E - zbytky dřevěné konstrukce stěny (obj. 50). Foto J. Hasil, 2013-2014.

Abb. 6. Erhalten gebliebene technische Details. A - Wärmedämmung der Gebäudewände (Obj. 36); B - Doppelwand der Duschen (Obj. 19); C - Wasserleitungsanschluss (Obj. 9); D - Kanalschächte in der Ecke der begehbaren Fläche (Obj. 109; 110); E - Reste einer Wandkonstruktion aus Holz (Obj. 50). Fotos J. Hasil, 2013-2014.

\section{Objekt 32}

Rozměry: $4 \times 4 \mathrm{~m}$

Popis: Špatně čitelný mírně konkávní objekt úhlové dispozice (ze čtverce chybí jihovýchodní kvadrant o velikosti $2 \times 2 \mathrm{~m}$ ).

Interpretace: Lehká pomocná stavba.

\section{Objekt 33}

Rozměry: $9 \times 8,5 \mathrm{~m}$ 
Popis: Téměř čtvercový objekt s betonovou základovou deskou, vně vysazenou jímkou a destrukcí komína.

Interpretace: Obytný objekt, snad se specifickým účelem vzhledem k přisazení k okraji mladší části areálu. Může jít např. o strážnici.

\section{Objekt 34}

Rozměry: $5 \times 3 \mathrm{~m}$

Popis: Zcela nevýrazný obdélný mírně konkávní objekt.

Interpretace: Lehká pomocná stavba.

\section{Objekty 35-66; 73}

Rozměry: Prostor s četnými objekty a stojícími konstrukcemi o rozloze ca $250 \times 200 \mathrm{~m}$

Popis: Areál těžebního a zpracovatelského závodu včetně pomocných staveb, obytných a administrativních budov, které jsou dochovány v podobě povrchových tvarů, betonových fundamentů a cihlových či železobetonových konstrukcí.

Interpretace: Interpretace objektů vychází z publikovaného plánu těžebního a úpravnického areálu (Rojík 2000, plán na s. 105, konkrétně jeho část severně od silnice Jelení - Přebuz). Jednotlivé objekty byly doplněny průběžným číslováním, které bude zachováno i v rámci následujících výzkumných aktivit. Z nejvýraznějších objektů je třeba zmínit především komplex reliktů rudného mlýna (obj. 56), rudných sil (obj. 57; obr. 7:A, B), úpravny (obj. 58; obr. 7:C) a zhuštovače kalů (obj. 59; obr. 7:D), k nimž na severu přiléhá betonová zátka jámy 1 (obj. 55). Nad ní se nacházela demontovaná těžní věž (viz výše), k níž vedly převody z budovy těžního stroje (obj. 52, východní část); západně od ní se nacházela kompresorovna (obj. 52, západní část) a trafostanice (obj. 53).

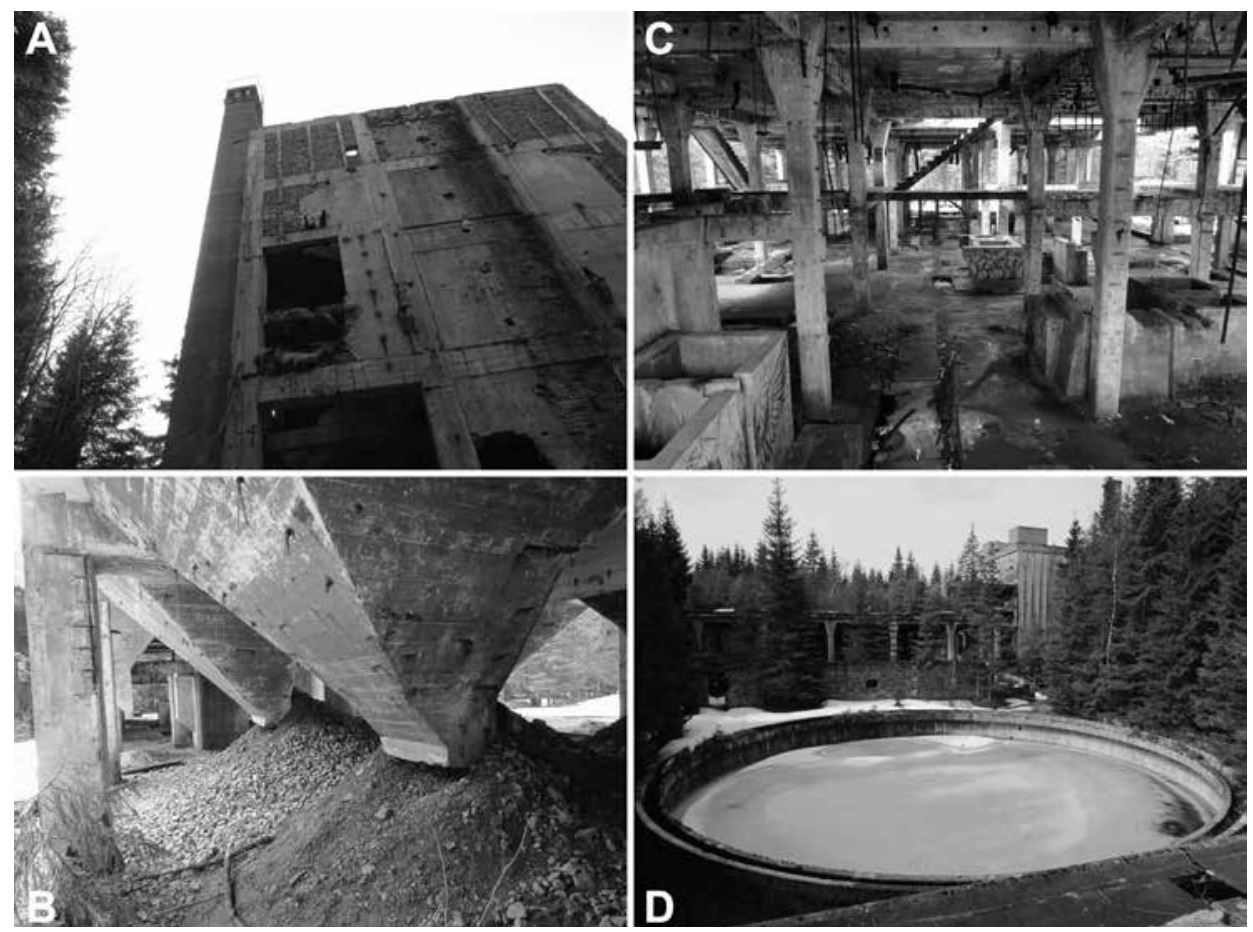

Obr. 7. Budovy zpracovatelského závodu. A - exteriér stavby rudných sil (obj. 57); B - násypky rudných sil stále naplněné rudninou (obj. 57); C - interiér úpravny rud (obj. 58); D - zhušt'ovač kalů (obj. 59). Foto J. Hasil, 2013-2014.

Abb. 7. Gebäude des Aufbereitungswerks. A - Erzsilo Außenansicht (Obj. 57); B - noch immer mit Erz gefüllte Schütttrichter (Obj. 57); C - Interieur der Erzaufbereitung (Obj. 58); D - Eindicker (Obj. 59). Fotos J. Hasil, 2013-2014. 
Ve východní polovině těžebního a zpracovatelského závodu se pak nacházelo technické a administrativní zázemí. Konkrétně jde o budovu ředitelství závodu (obj. 63), vrátnici s garáží a stájí (obj. 36; obr. 4:A, 6:A), již zmiňované obytné budovy (obj. 35 a 37), sklad cínového koncentrátu (obj. 40), skladovací budovu s nakládací rampou (obj. 42), tzv. dřevírnu (dílna zpracovávající dřevěné pažení - obj. 43), sklad (obj. 44), kovárnu a zámečnickou dílnu (obj. 50) a podsklepenou budovu s kanceláří štajgrů, kavnou civilních zaměstnanců a mužstva (obj. 51; obr. 5:C). Zajímavý nepravidelný konkávní objekt v sousedství úpravny (obj. 61) lze hypoteticky považovat za propad důlních prostor - pinku.

\section{Objekt 67}

Rozměry: $3 \times 2 \mathrm{~m}$

Popis: Mírně konkávní obdélný objekt.

Interpretace: Bez interpretace. Leží mimo areál tábora.

\section{Objekt 68}

Rozměry:-

Popis: Přibližně $0,5 \mathrm{~m}$ zahloubený liniový výkop. Jeho počátek zasahuje do svahu paty meze tvořící hranici tábora (obj. 122).

Interpretace: Strouha pro odvod odpadní vody z kanalizace.

\section{Objekt 69}

Rozměry: $16 \times 1,5 \mathrm{~m}$

Popis: Přibližně $1 \mathrm{~m}$ zahloubený liniový vkop, v polovině pravoúhle zalomený. Ve vrcholu zalomení se nachází otevřená šachta kanálu (obj. 100) a na východě jej přetíná recentní cesta.

Interpretace: Může souviset s úpravami kanalizace; jeho datace a souvislost s aktivitami „za života“ areálu je však nejasná a diskutabilní.

\section{Objekt 70}

Rozměry: průměr ca $6-8 \mathrm{~m}$

Popis: Nepravidelný kupovitý objekt s konkávním narušením (ca $2 \times 2 \mathrm{~m}$ ) v centrální části a s trojicí struh. Dvě z nich objímají objekt ze západní a východní strany, jedna sbíhá z jeho středu a všechny se u paty objektu spojují v jediný kanál vedoucí dále k severu. Šŕřka a hloubka struh se pohybuje okolo $50 \mathrm{~cm}$.

Interpretace: Funkce objektu je nejasná. Snad jde o výrobní zařízení, bez přímé souvislosti s důlním závodem.

\section{Objekt 71}

Rozměry: průměr ca $8-10 \mathrm{~m}$

Popis: Vyrovnaná kruhová plošina.

Interpretace: Pravděpodobně jde o milíŕriště.

\section{Objekt 72}

Rozměry: $3 \times 2 \mathrm{~m}$

Popis: Mírně konkávní obdélný objekt.

Interpretace: Bez interpretace. Leží mimo areál tábora.

\section{Objekty $74-121$}

Rozměry: celková délka kolem $1000 \mathrm{~m}$

Popis: Otevřené kanalizační šachty kruhového, výjimečně i obdélného tvaru. Kruhové šachty mají obvykle při ústí průměr ca $0,5 \mathrm{~m}$ a poté se betonové skruže rozšiřují do průměru ca $1 \mathrm{~m}$. Jejich hloubka je proměnlivá, nelze určit, jaká je původní niveleta dna, avšak dosahuje i několika metrů pod současným povrchem. Šachty jsou otevřené, často částečně překryté drnem a špat- 
ně zřetelné. Dvojice šachet je stále opatřena víky, patrně v nedávné době odhalenými hledači s detektory kovů (obj. 96 a 121). Víka kombinují užití litiny a betonu. Jednotlivé šachty byly propojeny kameninovým potrubím.

Interpretace: Vzhledem ke značně zamokřenému prostředí náhorní plošiny a pohybu několika stovek osob v rámci nevelkého areálu bylo nezbytné systematicky odvádět deštovou vodu mimo prostor tábora. Pro tento účel sloužil kanalizační systém, jehož průběh lze stopovat díky otevřeným šachtám. Tvoří jej pravoúhlá sít', osově shodná s dispozicí areálu. Linie probíhají po okrajích veřejných prostor mezi budovami a nacházejí se často při okraji dosud patrných pochozích ploch (obr. 6:D). Kanalizace ústila v jihozápadním, nejníže položeném rohu původního areálu (před jeho pozdějším rozšířením; viz obj. 31 a 68).

\section{Objekty 122-124}

Rozměry: celkem dochováno v délce $450 \mathrm{~m}$

Popis: Lineární útvary ohrazení tábora. Plocha tábora byla před jeho vybudováním částečně vyrovnána a vznikl tak terénní stupeň. Jeho svah obvykle směřuje vně areálu (areál je tedy převýšen nad původním terénem až o několik metrů), na severní straně je však místy i několik desítek centimetrů zahlouben. Linie není zachována celistvě a je přerušena postupnou erozí a mladším poškozením. Na jihovýchodní straně je v určitém úseku tvořena nízkým (ca $20 \mathrm{~cm}$ výšky) a širokým náspem. Na hraně místy vystupuje jednoduchá linie kamenů.

Interpretace: Areál byl plošně vyrovnán do přibližně stejné nivelety a ohrazen plotem s jednoduchou kamennou podezdívkou (pouze jedna řádka vertikálně i horizontálně). Sloupy plotu se $\mathrm{v}$ prostoru tábora nezachovaly.

\section{Objekty 125-126}

Rozměry: celkem dochováno $45 \mathrm{~m}$

Popis: Terénní stupeň o výšce $0,5-1,5 \mathrm{~m}$ se svahem ukloněným $\mathrm{k}$ jihu, osově shodný s orientací tábora.

Interpretace: Původní hranice tábora po jeho založení, později částečně planýrovaná.

\section{Objekt 127}

Rozměry: délka $180 \mathrm{~m}$; max. výška $5,5 \mathrm{~m}$

Popis: Sypaná hráz přehrazující údolí $500 \mathrm{~m}$ jižně od důlního závodu.

Interpretace: Umělá vodní nádrž vybudovaná pro zásobování důlního závodu vodou, dnes označovaná jako Rolavský rybník.

\section{Objekt 128}

Rozměry: nadzemní část $4 \times 2 \mathrm{~m}$; vnitřní prostor $3,5 \times 6 \mathrm{~m}$

Popis: Cihlová budova s železobetonovou střechou zapuštěná do tělesa obj. 127; zapuštěná část je zaklenuta cihlovou valenou klenbou.

Interpretace: V objektu byla usazena trojice pump pro zásobování areálu závodu vodou.

\subsection{Souhrn nalezených relikti̊}

Rozloha tábora činila původně $200 \times 80 \mathrm{~m}\left(16000 \mathrm{~m}^{2}\right)$ a průzkumem se podařilo prokázat jeho pozdější (avšak nedokončené) rozšíření směrem k jihu, čímž vzrostla ohrazená plocha na $200 \times 100 \mathrm{~m}\left(20000 \mathrm{~m}^{2}\right)$. Identifikováno zde bylo celkem 91 archeologických objektů; ty jsou vesměs orientovány shodně s osami tábora, a lze tedy důvodně předpokládat jejich rámcovou chronologickou souvislost.

Jde o:

- 27 pozůstatků budov (obj. 1-12; 16-20; 23-24; 26-30; 32-34)

- 5 blíže neidentifikovaných konkávních objektů (obj. 13-15) 
- 1 odpadní areál (obj. 25)

- objekty kanalizace

- 48 kanálových šachet (obj. 74-121)

- výpust' (obj. 31)

- odvodňovací strouhu (obj. 68)

- 2 liniové výkopy s paralelně deponovaným vytěženým materiálem (obj. 21-22)

- 1 nejednoznačně interpretovaný liniový vkop (obj. 69)

- 3 liniové relikty ohrazení tábora (obj. 122-124)

- 2 částečně planýrované relikty ohrazení tábora (obj. 125 a 126)

V prostoru těžebního a zpracovatelského komplexu bylo dosud rozpoznáno 39 objektů. Nejde však o konečné číslo, průzkum zde bude - vzhledem k velikosti areálu $\left(250 \times 200 \mathrm{~m} ; 50000 \mathrm{~m}^{2}\right)$ a značně nepřehlednému terénu - dokončen až v průběhu následujících let. Dosud identifikované objekty zahrnují:

- 24 do různé míry zachovalých budov (obj. 35-37; 40; 42-45; 48; 50-60; 62-63; 65-66)

- 4 konvexní objekty (patrně jde o planýrky; obj. 39; 46-47; 49)

- 1 neurčený konkávní objekt (obj. 41)

- 1 konstrukci neznámého účelu (obj. 38)

- 1 konkávní objekt interpretovaný jako pinka (obj. 61)

- 1 šachtu patrně související s odvětráváním dolu (obj. 64)

- 2 liniové stupně tvořící ohrazení areálu (obj. 127-128)

- 2 liniové stupně tvořící hranice ploch pro manipulaci s vytěženým materiálem a produkty zpracování (obj. 129-130)

V těsné blízkosti areálu leží:

- 1 konvexní objekt se žlaby a odtokovým kanálem (snad výrobního účelu; obj. 70)

- 1 milířiště (obj. 71)

- vodní nádrž Rolavský rybník (obj. 127) s objektem vodárny (obj. 128)

Dále byly namátkou objeveny stopy několika dalších konstrukcí a struktur, které nebyly do dokumentace zahrnuty a budou rekognoskovány v další fázi průzkumu. Jako prŕíklady lze uvést zbytky sloupů vysokého napětí, sloupky plotů, strukturování nezastavěných ploch apod. Prostor deponie výrobního a těžebního odpadu prozkoumán dosud nebyl, při jeho poznání se otvírá široký prostor pro využití dat leteckého laserového skenování. Pozornost by měla být věnována i širšímu okolí dolu, kde se nacházejí stopy starší těžby (obvalová pole).

\subsection{Interpretace objektů tábora a jeho vývoj}

Identifikované objekty lze rozdělit do několika typů podle různých kritérií. Mezi plošnými objekty vystupuje 14 konkávních povrchových útvarů, které většinou nevykazují stopy žádné konkrétní konstrukce. Dva největší (obj. 9 a 23) shodně interpretujeme jako pozůstatky obytných staveb, avšak v porovnání s podezděnými objekty (např. 27-29) jistě nižší kvalitativní úrovně. Dále je zde zastoupena skupina osmi téměř čtvercových jam, které často lze považovat za menší účelové dřevěné stavby (obj. 12;14; 15; 32; 34), s výjimkou objektu 31 spojovaného s vyústěním kanalizace. Objekt 13, obsahující množství odpadu, je podle archivních záznamů pozůstatkem toalet (latrín). V př́ípadě posledního z objektů této skupiny (obj. 7) jde snad o stanovišstě strážných, čemuž by nasvědčovala i poloha v nároží tábora (obr. 4:E). Dvě mírná obdélná zahloubení leží také v severním sousedství tábora (obj. 67; 72); o jejich souvislosti s ním - a tedy i o jejich funkci - však lze pouze spekulovat. 
Nízké konvexní útvary různé velikosti, avšak jen lehké dřevěné konstrukce, jsou spojovány se stavbami se specifickou funkcí. Bývají vybaveny otopným zařízením (obj. 1; 4; 26), jímkou (obj. 4; 26) či vodovodem (obj. 30). Jde o sklady dřeva a prádelny (obj. 1; 26), snad i kuchyni (obj. 4) a obytný dům (obj. 30). U objektů 1 a 26 je zřejmé dělení na několik prostor. Typologickou výjimku z celku tvoří nepravidelný objekt skládky (obj. 25).

Betonové základové desky či podezdívky identifikují pět protáhlých obdélných staveb (obj. 8; 11; 27-29). Jejich rozměry se pohybují mezi $17,5-40 \mathrm{~m}$ délky a o jisté typizaci svědčí jejich shodná šířka $8 \mathrm{~m}$ (v pramenech je zmiňována obvyklá šířka $8,15 \mathrm{~m}$; SOA P, kart. 20). Všechny tyto stavby zpřístupňují vně vysazená schodiště. Náznak otopného zařízení (plechový komínek; obr. 5:A) máme však pouze u objektu 11, kterému naopak jako jedinému z této skupiny chybí vodovodní př́ípojka. Zcela stejné rozměry, konstrukci i vybavení mají objekty 27-29; tato trojice totožných staveb byla připojena na kanalizaci. Lze se domnívat, že ve čtyřech případech jde o budovy pro ubytování internovaných osob (,Schlafbaracke“- obj. 8; 11; „Wohnbaracke“obj. 28; 29) a v jednom o kanceláře (obj. 27).

Betonovou podezdívku mají rovněž dvě atypické stavby. Jde o částečně podsklepený objekt úhlové dispozice (obj. 10) vybavený jímkou (umývárny) a téměř čtvercovou stavbu poblíž okraje tábora (obj. 33), zahrnující zděný komín a shodně s předchozím i jímku (nejspíše strážnice). Betonovou konstrukci má také dvojice podzemních prostor. V př́ípadě objektu 18 pozorujeme bývalou budovu latrín, objekt 6 jsou patrně lépe vybavené toalety.

Podstatně lépe se lze vyjádřit k funkcím dosud torzálně stojících ruin zděných cihlových konstrukcí. Nejrozsáhlejší z nich je budova vybavená mohutným komínem (obj. 3; obr. 5:B), která byla táborovou kuchyní a jídelnou, kombinovanou s obytným prostorem. Kuchyně byla podsklepená (sklepy osvětlovala velká okna) a zaujímala západní úsek stavby; jídelna snad doplňovala kuchyni v nepodsklepené části a navazující prostor na východě sloužil obytnému účelu. Mezi další zděné budovy patří konstrukčně zajímavý objekt sprch se zdvojenou izolační stěnou, spojený s latrínami (obj. 19), odvšivovací stanice s dvojicí komínů (obj. 16), vedle níž leží další podobný objekt s jedním komínem (obj. 17; obr. 4:D). Funkce není jasná u celistvě dochované nízké stavby v sousedství sprch (obj. 20), kterou lze s jistou opatrností považovat za trojici kotců. Jedna z dvojice budov opatřených betonovými polozapuštěnými sklepy překrytými drnem a přístupných po schodišti v cihlovém západním př́ístavku (obr. 4:B, C) byla skladovacím prostorem na uhlí (obj. 2) a druhá vězeňskou celou (obj. 5). Rozměry obou staveb se podstatně liší $(8 \times 4,5 \mathrm{~m}$ vs. $12 \times 7,5 \mathrm{~m})$, konstrukce a poměr stran jsou však shodné.

Těžko patrné jsou pozůstatky objektu 24, který tvoří pouze mírně vyrovnaná plocha a nezřetelná hrana na jihu a západě. Může jít o provizorní obytnou stavbu, jejíž odhadované rozměry $19 \times 7 \mathrm{~m}$ se nápadně přibližují rozměrům čtveřice montovaných domů (č. $4 ; 5 ; 7 ; 8)$ o délce $19,95 \mathrm{~m}$ a šiřce $8,14 \mathrm{~m}$, zmiňovaných $\mathrm{v}$ archivních pramenech (SOA P, kart. 7). Rozřešení této otázky je pro další výzkum klíčové, nebot' dotčený typ konstrukce, nezasahující významně do terénu, by vysvětloval skutečnost, proč se nepodařilo zbylé tři zmiňované obytné domky dosud nalézt. Mohly by se tak nacházet na zdánlivě nezastavěné ploše v jihozápadní části tábora. Svými rozměry by tuto plochu velmi racionálně zaplnily (srov. obr. 8) a jejich poloha a do jisté míry provizorní provedení by dobře korespondovalo se skutečnostmi prezentovanými níže.

Kromě plošných objektů byly identifikovány objekty bodové, které zastupují hlavně šachty kanalizace. O nich již bylo celistvě pojednáno v katalogu, nezbývá než zdůraznit některé aspekty daného řě̌ení.

Stoky vytvářely sít's délkou dosahující jednoho kilometru se spádem k jihozápadu. Zde se nacházela výpust' (obj. 31) odvádějící splaškovou vodu vně tábora, do strouhy směřující dále na jihozápad (obr. 8). Primární účel kanalizace byl nejspíše sběr deštové vody, nicméně minimálně objekty 27,28 a 29 na ni byly napojeny přímo.

Rozložení kanálů koresponduje se strukturováním veřejných prostor, které je v některých místech dosud zvýrazněno jednoduchou řádkou kamenů na svém okraji. Šachty kanálů jsou pak přiloženy k tomuto ohraničení, či jej přetínají (foto). 


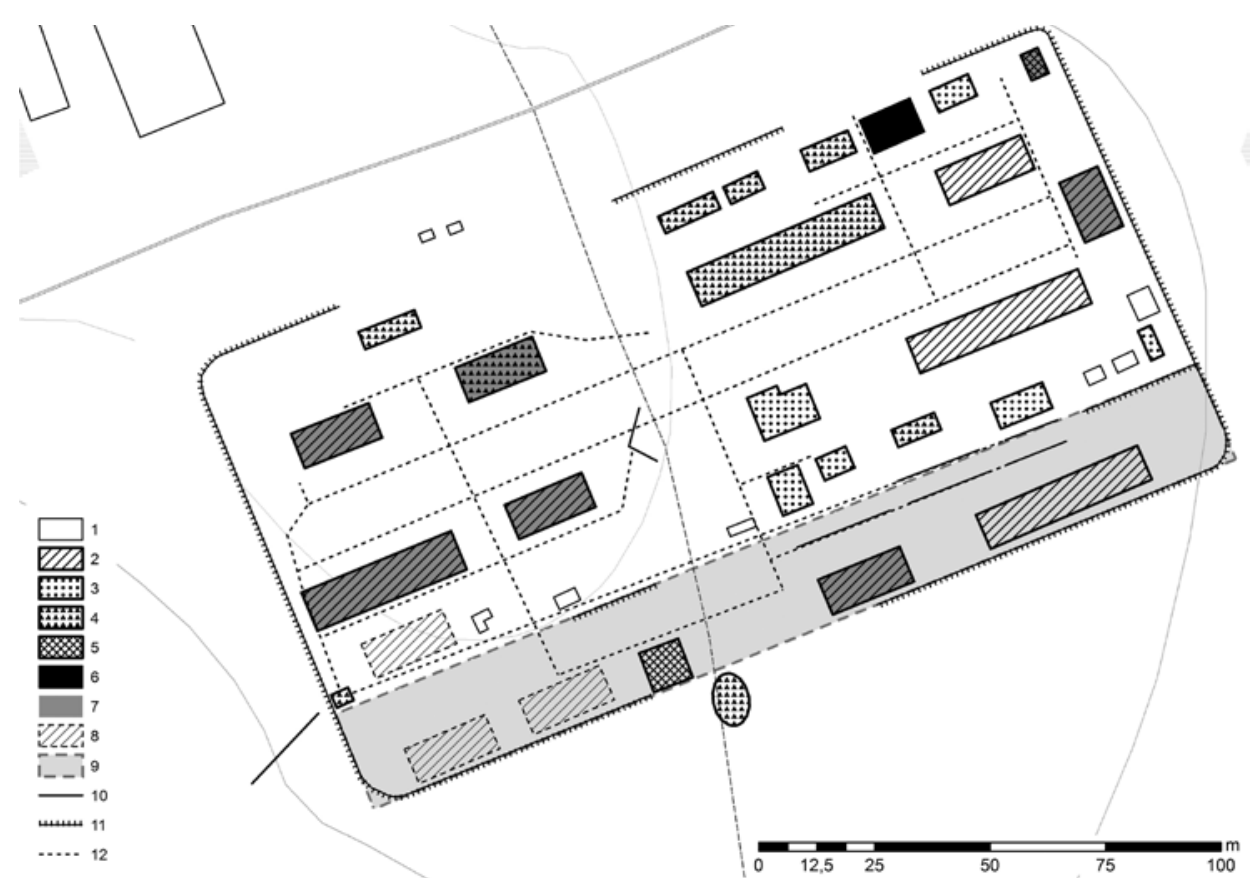

Obr. 8. Interpretační plán zajateckého tábora. 1 - objekty bez jednoznačné interpretace; 2 - obytné stavby; 3 - hygienické zařízení; 4 - provozní objekty; 5 - strážnice; 6 - vězeňská cela; 7 - „montované domky“ (srov. tab. 1); 8 - hypotetická poloha „montovaných domků“ č 5,7 a 8; 9 - rozšíření tábora; 10 - výkopy pro kanalizaci; 11 - hranice tábora; 12 - hypotetická rekonstrukce kanalizační sítě. Zaměření a plán D. Novák, J. Hasil.

Abb. 8. Interpretationsskizze des Gefangenenlagers. 1 - Objekte ohne eindeutige Interpretation; 2 - Wohngebäude; 3 - Sanitäranlagen; 4 - Betriebsobjekte; 5 - Wachstube; 6 - Gefängniszelle; 7 - „montierte Häuschen“ (vgl. Tab. 1); 8 - hypothetische Lage der „montierten Häuschen“ Nr. 5, 7 und 8; 9 - Vergrößerung des Lagers; 10 - Kanalisationsgräben; 11 - Lagergrenze; 12 - hypothetische Rekonstruktion des Kanalisationsnetzes. Vermessung und Planskizze D. Novák, J. Hasil.

Identifikace kanalizační sítě, která není zachycena v dostupných archivních pramenech, má důsledky mj. pro interpretaci liniových zahloubených objektů 21 a 22 . Ty totiž nejsou ničím jiným než výkopy pro novou část kanalizace budovanou v souvislosti s rozšířením tábora, která však nebyla nikdy dokončena. Terénní situace postihuje stav, kdy do západní části výkopu 21 byly položeny kanalizační trubky a výkop byl již zasypán. Zbytek však zůstal, snad v důsledku blížící se německé porážky, nedokončen.

Nejde o ojedinělý terénní doklad předložené hypotézy o rozšiřování tábora jihovýchodním směrem; dalším zcela zásadním důkazem růstu tábora je př́itomnost liniových stupňủ (obj. 125 a 126) ukloněných $\mathrm{k}$ jihu, které vymezují původní hranici před rozšiřením areálu v celé jeho délce přesně o $20 \mathrm{~m}$ směrem k jihu. Př́mým dokladem je také poloha vyústění kanalizace (obj. 31), které se nachází v jihozápadním, nejníže položeném nároží původní plochy tábora. Výpust' tak leží přesně na průsečíku pomyslné přímky tvořené linií objektů 125 a 126 se stávajícím ohrazením (obj. 122).

Tato interpretace přináší mnohá vysvětlení pro další řešené otázky. Prvním je zjevná diskrepance mezi plány tábora nesoucími datum 9. února 1942 (SOA P, kart. 2) a 14. února 1943 a terénní situací. Druhé se týká očividně odlišné konstrukce objektů 23 a 24, které představují do jisté míry provizorní řešení ubytování přibývajících zajatců. Přináší také klíč k výkladu rozsáhlé, zdánlivě prázdné plochy v jihozápadním nároží areálu. Jak již bylo řečeno výše, právě lehká, do terénu se nepromítající konstrukce domků (stejného typu, jako obj. 24) mohla zapř́íčinit úplné setření jejich stop po zrušení tábora. Hypotézu o jejich „zmizeni““ podporují i archivní dokumenty týkající se jejich demontáže a prodeje drahám (viz výše). I přes nedokončený projekt rozššření tábora byl při jeho okraji vybudován objekt 33 , který byl stavěn prioritně a pravděpodobně tak 


\begin{tabular}{|c|c|c|c|c|c|}
\hline \multicolumn{3}{|c|}{ podle písemné evidence } & \multicolumn{3}{c|}{ podle archeologické evidence } \\
\hline číslo domku & délka $[\mathrm{m}]$ & šířka $[\mathrm{m}]$ & číslo objektu & délka [m] & śírka [m] \\
\hline č. 1 & 17,75 & 8,14 & 27 & 17,5 & 8 \\
\hline č. 2 & 17,75 & 8,14 & 28 & 17,5 & 8 \\
\hline č. 3 & 23,25 & 8,14 & - & - & - \\
\hline č. 4 & 19,95 & 8,14 & 24 & $19(?)$ & $7(?)$ \\
\hline č. 5 & 19,95 & 8,14 & - & - & - \\
\hline č. 6 & 15 & 8,14 & 9 & 14 & 9 \\
\hline č. 7 & 19,95 & 8,14 & - & - & - \\
\hline č. 8 & 19,95 & 8,14 & - & 17,5 & 8 \\
\hline č. 10 & 17,75 & 8,14 & 29 & 34,5 & 9 \\
\hline č. 11 & 34 & 8,14 & 30 & $6,5(6)$ & $4(5,5)$ \\
\hline č. 20 & 6,75 & 4,61 & 7 či 12 & $6,5(6)$ & $4(5,5)$ \\
\hline č. 21 & 6,75 & 4,61 & 7 či 12 & & - \\
\hline
\end{tabular}

Tab. 1. Ztotožnění a komparace rozměrů písemně doložených „montovaných domkü“ (podle SOA P, kart. 7) s výsledky geodeticko-topografického průzkumu.

Tab. 1. Identifizierung und Vergleich der Abmessungen der schriftlich belegten „montierten Häuschen“ (gemäß Staatl. Gebietsarchiv Pilsen, Kart. 7) mit den Ergebnissen der geodätisch-topographischen Untersuchung.

nesloužil vězňům, ale pro potřeby táborové správy. Na novém okraji areálu se tak ocitla i sousední, dodnes snad víceméně neporušená skládka odpadu (obj. 25).

Výše zmiňované údaje o odvozu montovaných domků jsou dalším příkladem ukázkové korelace mezi výpovědí psaných a archeologických pramenů. Celkem bylo zvažováno odvezení 12 domků, u nichž známe i jejich přesné rozměry. Domy č. 1, 2 a 10 se rozměry shodují s objekty 27-29. Domek č. 6 lze ztotožnit s erozí deformovaným objektem 9, č. 11 s objektem 30 a č. 20 či $21 \mathrm{~s}$ objektem 7. Pro druhý z této dvojice by mohl přicházet v úvahu objekt 12 , rozměry zde však nekorespondují přesně. O ztotožnění domku č. 4 s objektem 24 již bylo pojednáno výše. Domek č. 3 svými rozměry bohužel neodpovídá žádnému z objektů tábora (podrobně viz tab. 1).

Podstatnou otázkou je vnitřní členění areálu tábora, které lze sledovat na základě výše uvedených dokladů a interpretací (obr. 8). Základem byla větší, východní část zabírající plochu $100 \times 80 \mathrm{~m}\left(8000 \mathrm{~m}^{2}\right)$. Zde se nachází většina provozních staveb (kuchyně, jídelna, prádelna, skladovací prostory) a kompletní hygienické zařízení (latríny/toalety, sprchy, umývárna, odvšivovací stanice). V takto vymezeném rámci byl pouze omezený prostor pro stabilní obytnou zástavbu či méně komfortní montované domky přimykající se k východnímu okraji areálu.

Naproti tomu západní část byla vymezena především k obývání. Obytné stavby zde byly podstatně lépe vybavené, mj. s napojením na kanalizaci. Výjimku tvoří objekt 30 , který byl patrně jednodušší konstrukce a vzhledem k velikosti sloužil k ubytování více osob. Nacházela se zde i kancelářská budova táborové správy. Severněji položená budova, která nese stopy po cihlovém otopném zařízení (typologicky ji lze spojovat s objekty 1 a 4), byla prádelnou. Je zajímavé, že kromě prádelny byly všechny domy v této části tábora označovány po válce jako „montované“ a určené k odvozu.

Jižní linii tábora, vytyčenou objekty 125 a 126, lemovaly malé dřevěné stavby, jejichž účel by snad osvětlil archeologický výzkum; pravděpodobně šlo o kủlny a podobné pomocné stavby.

Někdy v průběhu války došlo $\mathrm{k}$ rozšíření tábora o $20 \mathrm{~m}$ jižním směrem. To zapříčinilo zánik původního vymezení a vytvoření nového ohrazení, které reprezentuje dodnes výrazná jižní hranice tábora (obj. 122; 124). Nedlouho poté byla postavena strážnice (?) při dnešní cestě, která respektuje průběh tehdejší komunikace (srov. HISTORICKÉ ORTOFOTO; obr. 3). V této souvislosti byly vybudovány také dvě nové budovy v jihovýchodní části tábora a byla započata 
stavba dalších úseků kanalizace. Na volném prostranství v jihozápadním rohu pak byly patrně postaveny jednoduché montované domy.

\section{Závěr}

Obojí, tedy písemná a hmotná evidence zániku rolavského důlního závodu a přilehlého zajateckého tábora jako sociálně-ekonomického organismu zahrnuje mnoho uzlových bodů, kde se tyto výpovědi protínají, či vhodným způsobem doplňují. Písemné prameny velmi přesně datují intencionální zásahy vůči funkční celistvosti areálu do úzkého chronologického intervalu od února 1946 do léta 1947; archivní rešerše doložila, které předměty, součásti infrastruktur i celé konstrukce byly záměrně odstraněny z válkou nepoškozeného a technicky vyspělého závodu, $\mathrm{k}$ jehož znovuuvedení do provozu chyběla pouze pracovní síla a provozní kapitál. Díky tomu je možno dovodit, která část hmotného záznamu podléhala zániku postupně a neorganizovaně až v mladších obdobích. Proces přeměny na archeologické prameny poté probíhal (a probíhá) bud' v souvislosti s přirozenými procesy degradace jednotlivých konstrukcí, nebo v důsledku záměrného sběru a odvážení kovových artefaktů za účelem zpeněžení.

Na lokalitě proto dokážeme rozlišovat jak primární, krátkou, intencionální archeologizaci, tak následný neřízený fyzický rozklad poměrně komplexní struktury. Ten je v př́ípadě některých konstrukcí již v zásadě dokončen (dřevěné stavby), zatímco jiné lze v současné době pozorovat v průběhu tohoto procesu (např. cihlové konstrukce). Další, hlavně železobetonové stavby - pokud nebyly narušeny např. záměrnými demontážemi či mladším rabováním železných komponent - zůstávají doposud víceméně intaktní. Je třeba na tomto místě zdůraznit, že podobná pozorování „standardni““ archeologické situace zpravidla nenabízejí.

Rolavský důlní areál nabízí i významné impulsy pro poznání hmotné kultury. Při každé z badatelských návštěv bylo možno pozorovat četné terénní zásahy způsobené ilegálními archeologickými výzkumy prováděnými vesměs za použití detektorů kovů; memento této takřka „každodenni““ ztráty informace představuje cínový odlitek ve tvaru psí hlavičky, snad těžítko, vytvořené tzv. metodou ztraceného vosku (obr. 9). Tento předmět některý z tzv. hledačů odložil v areálu lágru na pařez, nebot' $v$ cínovém slitku nepoznal impresivní svědectví o každodennosti nuceně pracujících. Podobné nálezy, spojené s krácením dlouhé chvíle a trávením volného času $\mathrm{v}$ prostředí do značné míry neprrátelském, nehostinném a zároveň monotónním, jsou přitom jedním z témat, jejichž výpovědní hodnota ve vztahu k lidským osudům v době nesvobody či války dosud nebyla patřičně doceněna, a je velmi aktuální i pro archeologii 20. století (srov. Saunders 2003). V souvislosti s drobnými, ale velmi četnými narušeními archeologických situací však ztrácejí svůj kontext i jiné předměty, mimo jiné porcelánové a skleněné nádoby a jejich zlomky, kovové předměty (např. jídelní misky) či zbytky obuvi.

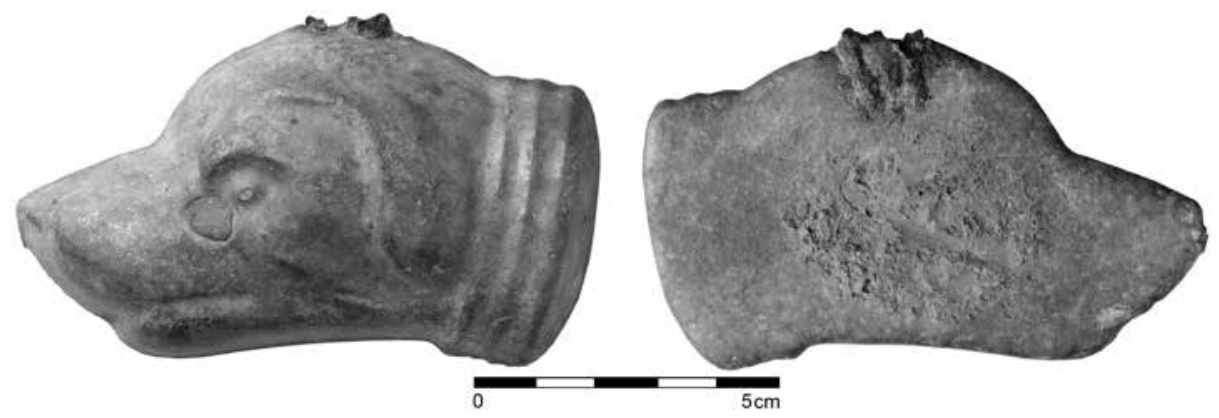

Obr. 9. Cínový odlitek ve tvaru psí hlavičky nalezený v areálu tábora, původně vyzvednutý v rámci nelegálního průzkumu detektorem kovů. Foto Z. Kačerová, 2014.

Abb. 9. Im Lagerareal gefundener Zinnabguss in Form eines Hundekopfes, der ursprünglich bei einer illegalen Metalldetektorsuche gehoben wurde. Foto Z. Kačerová, 2014. 
Důlní areál a přilehlý komplex tábora jsou jedněmi z mála dosud identifikovaných objektů, kde lze na českém území systematicky studovat postupy represivního režimu v období druhé světové války - téma nadmíru diskutované především v zahraniční literatuře (srov. Mytum-Carr edd. 2012; Theune 2010a; González-Ruibal 2012). Lokalita nabízí srovnávací materiál nejen k výzkumům vlastních vyhlazovacích táborů (srov. Gilead-Haimi-Mazurek 2009) a k souvisejícím soudobým tématům v českém prostředí (napřr. pochody smrti; srov. Nenutil-Rak edd. 2011), ale také k rozvíjejícímu se studiu represe prováděné Čechoslováky vůči sudetským Němcům (např. řada prací věnujících se zániku vsí po roce 1945; srov. Vařeka 2013a, 165; Vařeka-Balý-Funk-Galusová 2008), případně utlačování vlastního obyvatelstva komunistickým režimem (srov. Světlík-Symonds-Vařeka 2014; Šafanda 2012). V této rovině se archeologická věda dostává do pozice aplikovaného oboru, nebot' se svým způsobem podílí na řešení dosud aktuálních společenských otázek. Ty souvisí jak s vyrovnáním se s vlastní minulostí, tak s pochopením podobných procesů a represivních postupů v současné společnosti, což prokazují i množící se publikace a běžící odborná diskuse (srov. Głosek 1996; González-Ruibal 2009; 2014; González-Ruibal-Moshenska 2015; Panhuysen 2014; Rak 2013), ve které se výzkumné otázky střetávají $\mathrm{s}$ etickými. V neposlední řadě pak otvírá průzkum rolavského důlního závodu a zajateckého tábora i doposud dlouhodobě opomíjené téma nucené práce osob cizí národnosti na území dnešní ČR (viz Kokošková-Pažout-Sedláková 2011; srov. Spoerer 2005).

Je tedy zřejmé, že tento př́íspěvek je pouze prvním krokem na delší cestě a že na mezioborově složené badatelské kolektivy čeká na hřebeni Krušných hor ještě celá řada výzev i naléhavých úkolů. Mezi nimi lze jmenovat zejména průzkum reliktů technologických zařízení a jejich rekonstrukce s důrazem na objekt úpravny rud, jejíž technologická specifikace není v archivních pramenech dostatečně podchycena; z metodického hlediska půjde o pozoruhodnou aplikaci vpravdě mikrotopografického průzkumu. Druhým klíčovým tematickým okruhem jsou otázky spojené s běžným provozem závodu a s artefaktuálními projevy př́ítomnosti kontrastních sociálních skupin, které užívaly jednotlivé dílčí areály; do této komparace vstupují nejen obytné a provozní objekty závodu a prrilehlého zajateckého tábora, ale také blízká obec Rolava, jejíž zánik lze datovat do stejného období jako zánik důlního komplexu samého. Jako relevantní vystupují zejména otázky vzájemné interakce těchto sociálních prostředí, shody a odlišnosti $\mathrm{v}$ př́ístupu $\mathrm{k}$ různým druhům spotřebního zboží a potravin a prostorová distribuce artefaktů (např. součástí vojenské výstroje), které symbolicky vyjadřují státní příslušnost. Pro řešení těchto otázek padá do úvahy samozř̉ejmě celá řada metodických postupů a jejich kombinací, z jejich širokého spektra jmenujme mimo jiné archeologický odkryv zejména odpadních areálů (deponie odpadu - obj. 25, latríny - obj. 18 a 19), systematický průzkum detektorem kovů, aplikace (mikro)GIS a mnohé další. Zároveň je třeba pokračovat v interdisciplinární spolupráci, zejména formou rešerší v rámci zahraničních archivů; aspekty ekonomického fungování závodu v době druhé světové války mohou osvětlit písemnosti uložené ve fondech říšského ministerstva financí (Bundesarchiv Berlin), nebot' z excerpovaných dokumentů vyplývá, že provoz strategicky důležitého, nicméně ztrátového závodu byl třetí říší dlouhodobě dotován. K otázce pracovně nasazených válečných zajatců, která je v materiálu dochovaném na území ČR značně podreprezentována, se pak jako perspektivní jeví armádní odbočka Bundesarchivu ve Freiburgu im Breisgau (Militärarchiv).

\section{Prameny, zdroje a literatura}

FORBES, N.-PAGE, R.-PÉREZ, G., 2009: Europe's Deadly Century. Perspectives on 20th Century Conflict Heritage. Swindon.

FUNARI, P.-ZARANKIN, A.-SALERNO, M., edd., 2010: Memories from Darkness: Archaeology of Repression and Resistance in Latin America. New York.

GILEAD, I.-HAIMI, Y.-MAZUREK, W., 2009: Excavating Nazi Extermination Centres, Present Pasts 1, $10-39$. 
GŁOSEK, M., 1996: Archeologiczne aspekty badań cementarzy polskich oicerów zamordowanych przez NKWD na wschodzie. In: Słowiańszczyzna w Europie Średniowiecznej 2 (Kurnatowska, Z., ed.), 259-268. Wrocław.

GONZÁLEZ-RUIBAL, A., 2009: Topography of terror or cultural heritage? The monuments of Franco's Spain. In: Europe's Deadly Century. Perspectives on 20th century conflict heritage (Forbes, N.Page, R.-Pérez, G., edd.), 65-72. Swindon.

- 2012: From the battlefield to the labour camp: archaeology of Civil War and dictatorship in Spain, Antiquity $86,456-473$.

- 2014: Returning to where we have never been: excavating the ruins of modernity. In: Ruin Memories Materialities, Aesthetics and the Archaeology of the Recent Past (Olsen, B.-Pétursdóttir, P., edd.), 367-389. London.

GONZÁLEZ-RUIBAL, A.-MOSCHENSKA, G., edd., 2015: Ethics and the Archaeology of Violence. New York.

HISTORICKÉ ORTOFOTO: http://kontaminace.cenia.cz, cit. 29. 11. 2014.

KOKOŠKOVÁ, Z.-PAŽOUT, J.-SEDLÁKOVÁ, M., 2011: Pracovali pro třetí říši. Praha.

KOLA, A., 2000: Bełżec. The Nazi Camp for Jews in the Light of Archaeological Sources. Excavations 1997-1999. Warsaw - Washington.

KOLÁŘ, J.-MACHÁČEK, J., 2014: rec. David Válek a kol.: Sídliště kultury s moravskou malovanou keramikou v Hlubokých Mašůvkách (výzkumy z let 1947-1950), AR LXVI, 548-551.

KUNA, M. a kol., 2014: Archeologický atlas Čech. Vybrané památky od pravěku do 20. století - Archaeological Atlas of Bohemia. Selected Sites from Prehistory to the 20th Century. Praha.

LAUBER, W., 2004: Sauersack - ein verschwundenes Dorf in Erzgebirge. Schönheide.

MYTUM, H.-CARR, G., edd., 2012: Prisoners of War: Archaeology, Memory, and Heritage of 19th- and 20th-Century Mass Internment. New York.

NENUTIL, J.-RAK, M., edd., 2011: Exhumace obětí II. světové války - předpoklady, východiska, výzkum. Plzeň.

NEUSTUPNÝ, E., 2013: Archeologie modernity - teoretický kontext. In: Archeologie 19. a 20. století: Př́istupy - Metody - Témata (Vařeka, P., ed.), 13-16. Plzeň.

PANHUYSEN, R., 2014: From Scene of Crime to Heritage: How Can We Investigate Recent Mass Graves while Taking into Account Their Role in Commemorative Practices? Oral presentation, CHAT 2014 meeting, Pilsen.

PFOHL, E., 1922: Orientierungslexikon der Tschechoslowakischen Republik. Reichenberg.

RAK, M., 2013: Archeologie konfliktů 20. století. In: Archeologie 19. a 20. století: Přístupy - Metody - Témata (Vařeka, P., ed.), 115-136. Plzeň.

ROJÍK, P., 2000: Historie cínového hornictví v západním Krušnohoří. Kouzlo hornické Přebuzi, Nejdku a jejich okolí - Geschichte des Zinnbergbaus im westlichen Erzgebirge. Zauber der Bergstädte Frühbuss und Neudek und deren Umgebung. Sokolov.

- 2005: Tin deposits at Přebuz and Rolava in the Krušné hory / Erzgebirge, Czech Republic: classic localities, new challenges - Cínová ložiska u Přebuzi a Rolavy v Krušných horách, Česká republika: klasické lokality, nové výzvy, Journal of the Czech Geological Society 50, 157-165.

- 2010: Historischer Zinnbergbau im Westerzgebirge (Krušné hory), am Beispiel der Zinnreviere Přebuz (Frühbuß) und Horní Blatná (Platten), Der Aufschluss 61, 239-260.

SAUNDERS, N. J., 2003: Trench Art: Materialities and Memoires of War. Oxford.

SOA P: Státní oblastní archiv Plzeň, fond Cínové doly Rolava 1906-1950 (nezpracovaný archivní fond částečně přístupný pro nahlížení).

SPOERER, M., 2005: Nucené práce pod hákovým křížem. Praha.

SVĚTLÍK, R.-SYMONDS, J.-VAŘEKA, P., 2014: Divided Landscapes, Divided Peoples: An Archaeology and Anthropology of the Iron Curtain. Oral presentation, CHAT 2014 meeting, Pilsen.

ŠAFANDA, J., 2012: Možnosti archeologie 20. století - Tábory nucených prací. Nepublikovaná bakalářská práce na KAR FF ZČU v Plzni.

THEUNE, C., 2006: Vier Tonnen Funde geborgen. Eine Müllgrube im ehemaligen Konzentrationslager Sachsenhausen, Stadt Oranienburg, Lkr. Oberhavel, Archäologie in Berlin und Brandenburg 2006, 131-133.

- 2010: Archäologische Relikte und Spuren von Tätern und Opfern im ehemaligen Konzentrationslager Mauthausen. In: Mauthausen Memorial neu gestalten. Tagungsbericht zum 1. Dialogforum. 18.-19. Juni 2009, 33-38. Wien.

- 2010a: Historical archaeology in national socialist concentration camps in Central Europe, Historische Archäologie 2010 [on-line]. Dostupné z: http://www.histarch.uni-kiel.de/2010_Theune_high.pdf. 
VǍ̌EKA, P., ed., 2013: Archeologie 19. a 20. století: Př́ístupy - Metody - Témata. Plzeň.

- 2013a: Přehled kvalifikačních prací zaměřených na archeologii modernity na katedře archeologie Fakulty filozofické Západočeské univerzity v Plzni do roku 2012. In: Archeologie 19. a 20. století: Př́istupy Metody - Témata (Vařeka, P., ed.), 165-169. Plzeň.

VAŘEKA, P.-BALÝ, R.-FUNK, L.-GALUSOVÁ, L., 2008: Archeologický výzkum vesnic středověkého původu na Tachovsku zaniklých po roce 1945 - Die archäologische Grabung der nach 1945 verschwundenen Dörfer mittelalterlichen Ursprungs in der Tachauer Gegend, AH 33, 101-117.

WEBER, N., 2001: Rolava: Cínový důl Sauersack, Krasová deprese 9, 2-8.

\section{Zusammenfassung}

Der Tod der Grube Sauersack (Rolava), Bez. Sokolov (Falkenau). Der Untergang eines Bergwerkbetriebes aus fachübergreifender Sicht

Die unterschiedlichen Kategorien archäologischer Funde machen einen unterschiedlichen Erkenntnisprozess der Archäologisierung möglich und gleichzeitig erforderlich, jedoch können verschwindende und sich transformierende ursprüngliche Strukturen von der Archäologie in der Regel höchstens modelliert werden. Aus methodischer Sicht ist es deshalb fruchtbar, auch in solchen Fällen archäologische Erkenntnisverfahren heranzuziehen, in denen die Form einer lebendigen Kultur für den Forscher entweder autooptisch bekannt oder ständig sehr nahe ist, bzw. er sie anhand einer alternativen, besonders schriftlich, als Karte und ggf. in Bildern vorliegenden Dokumentation studieren kann. Die Gewinnung von Erkenntnissen über chronologisch nahe Zeiträume (Die Moderne) anhand von archäologischen Methoden muss als aktuelle Aufgabe angesehen und entwickelt werden. Hier eröffnet sich eine hervorragende Möglichkeit, eine Quellenkritik nicht in der Relation „objektive Feststellung - Modell“, sondern auf der Ebene „objektive Feststellung - objektive Feststellung“ zu erschließen, also auf Ebene der allgemeinen Theorie der Artefakte. Gleichzeitig ist zu betonen, dass infolge einer Stärkung des kollektiven historischen Bewusstseins der bürgerlichen Gesellschaft sich bereits seit den neunziger Jahren des 20. Jahrhunderts in den westlichen Ländern eine Archäologie ,dunkler Epochen“ entwickelt, in der die artefaktuelle Ebene mit ihrer speziellen Perspektive den Ereignissen einen Rahmen gibt, die nicht vergessen werden dürfen. Die Archäologie erhält dadurch die Gelegenheit, ihrer gesellschaftlichen Aufgabe im Rahmen einer Problematik nachzukommen, die für eine breitere Hörergemeinde gut verständlich ist und dadurch auch die allgemeine Wirkung und die Vertrauenswürdigkeit des Faches insgesamt stärkt. Der vorgelegte Text soll zu beiden Herausforderung, mit denen sich die heutige Archäologie konfrontiert sieht, einen Beitrag leisten. Er entstand in den Jahren 2012-2014 im Rahmen der Forschungsaktivitäten des Prager Archäologischen Instituts der Akademie der Wissenschaften der Tschechischen Republik, sowie seit 2014 im Rahmen einer am Lehrstuhl für Geschichte der Jan-Evangelista-Purkyně-Universität in Ústí nad Labem vergebenen Bachelor-Arbeit. Die vorläufigen Ergebnisse der archäologischen Untersuchung und umfangreichen Archivrecherche werden in Form einer Fallstudie zur Problematik des Untergangs und der Archäologisierung des Bergwergbetriebs Sauersack präsentiert.

Das Gelände des 1940 gegründeten Sauersacker Betriebes gliedert sich in zwei Teile. Während das Abbau- und Weiterverarbeitungsareal (Abb. 1, Fläche A) und dessen Umfeld eine bislang gut verständliche Struktur ist, was bereits aus vielerlei Blickwinkeln durch das erhaltene Archivmaterial sehr anschaulich angedeutet wird, stellte das Verstehen der Überreste des angrenzenden Gefangenenlagers (Abb. 1, Fläche B) für eine detaillierte geodätisch-topographische Untersuchung eine Aufgabe dar, welche über die Bebauung innerhalb des Areals und dessen funktionelle Unterteilung in einzelne Zonen grundlegende Erkenntnisse lieferte. Grundlage dafür war der größere östliche Teil (siehe Abb. 2), der eine Fläche von $100 \times 80 \mathrm{~m}\left(8000 \mathrm{~m}^{2}\right)$ einnimmt. Dort befanden sich die meisten Betriebsgebäude (Küche, Kantine, Wäscherei, Lagerräume) und die kompletten sanitären Anlagen (Latrinen/Toiletten, Duschen, Waschraum, Entlausungsstation). In diesem abgegrenzten Rahmen gab es nur begrenzt Raum für eine stabile 
Bebauung mit Wohngebäuden bzw. weniger komfortable Fertighäuser, die an den Ostrand des Areals anschlossen.

Demgegenüber war der Westteil vor allem zu Wohnzwecken abgegrenzt. Die dortigen Wohngebäude waren besser ausgestattet, u.a. mit Anschluss an die Kanalisation. Eine Ausnahme bildet Objekt 30, das offenbar eine einfachere Baukonstruktion hatte und hinsichtlich seiner Größe zur Unterbringung von mehreren Personen diente. Dort befand sich auch das Bürogebäude der Lagerverwaltung. Bei dem nördlicher gelegenen Gebäude, das Spuren einer Heizanlage aus Ziegelsteinen aufweist (typologisch kann es mit den Objekten 1 und 4 in Verbindung gebracht werden), handelte sich um die Wäscherei. Es ist interessant, dass außer der Wäscherei alle Häuser in diesem Teil des Lagers nach dem Krieg als „montiert“ bezeichnet wurden und zum Abtransport bestimmt waren (siehe Tab. 1).

Die mit den Objekten 125 und 126 abgesteckte südliche Linie des Lagers war mit kleinen Holzbauten gesäumt, deren Zweck vielleicht durch eine archäologische Grabung geklärt werden könnte; wahrscheinlich handelte es sich um Schuppen und ähnliche Hilfsbauten. Irgendwann während des Krieges wurde das Lager nach Süden hin um 20 m vergrößert. Das hatte zur Folge, dass die ursprüngliche Abgrenzung verschwand und eine neue Einfriedung geschaffen wurde, die bis heute die markante Südgrenze des Lagers repräsentiert (Obj. 122; 124). Kurz danach wurde am heutigen Weg, der den Verlauf des damaligen Weges respektiert, ein Verwaltungsgebäude (Obj. 33) errichtet. In diesem Zusammenhang wurden auch zwei neue Gebäude im südöstlichen Teil des Lagers gebaut und mit dem Bau von weiteren Abschnitten der Kanalisation begonnen. Auf einem freien Platz in der südwestlichen Ecke wurden dann offensichtlich einfache Fertighäuser errichtet. Die Lagererweiterung spiegelt sich in den bis dato studierten Archivdokumenten gar nicht.

Beide, d.h. die schriftlichen und materiellen Zeugnisse des Untergangs des Bergwerkbetriebs Sauersack und des daran angrenzenden Gefangenenlagers als sozialökonomischer Organismus enthalten viele Knotenpunkte, an denen ihre Aussagen ineinander übergehen oder sich entsprechend ergänzen. Die schriftlichen Quellen datieren die intentional erfolgten Eingriffe gegenüber dem funktionellen Wesen des Areals sehr genau in das enge chronologische Intervall zwischen Februar 1946 und Sommer 1947; durch die Archivrecherche wurde belegt, welche Gegenstände, Teile der Infrastruktur und ganze Konstruktionen aus dem vom Krieg nicht beschädigten und technisch intakten Betrieb, zu dessen Wiederinbetriebnahme lediglich Arbeitskräfte und Betriebskapital fehlten, absichtlich entfernt wurden. Aufgrund dessen kann man dahingehend Schlussfolgerungen ziehen, welcher Teil der materiellen Zeugnisse erst in jüngerer Zeit einem allmählichen und unorganisierten Zerfall unterlag. Der Umwandlungsprozess zu archäologischen Quellen erfolgte (und erfolgt) dann entweder im Zusammenhang mit natürlichen Zerfallsprozessen der einzelnen Konstruktionen oder infolge einer absichtlichen Demontage und des Abtransports von Artefakten aus Metall, mit dem Ziel, diese zu Geld zu machen.

An der Fundstelle können wir deshalb sowohl eine primäre, kurze, intentionale Archäologisierung, als auch den anschließenden ungeregelten physischen Zerfall einer relativ komplexen Struktur unterscheiden. Dieser ist im Falle einiger Konstruktionen im Grunde genommen bereits beendet (Holzbauten), während man bei anderen gegenwärtig den Verlauf dieses Prozesses beobachten kann (z.B. Ziegelbauten). Weitere Bauten, hauptsächlich Eisenbetonskelette, sind falls sie etwa nicht durch absichtliche Demontagen oder jüngere Plünderungen der Eisenbestandteile gestört wurden - bis heute mehr oder weniger intakt geblieben. An dieser Stelle muss betont werden, dass ähnliche Beobachtungen von einer archäologischen „Standardsituation“ in der Regel nicht geboten werden.

Das Sauersacker Grubenareal bietet auch bedeutende Impulse für Erkenntnisse über die Sachkultur. Bei jedem Forschungsbesuch konnten zahlreiche Geländeeingriffe beobachtet werden, die durch illegale archäologische Grabungen unter Verwendung von Metalldetektoren verursacht wurden; ein Memento für diesen quasi „alltäglichen“ Informationsverlust stellt ein Zinnabguss in Form eines Hundekopfes dar, bei dem es sich wohl um einen Briefbeschwerer handelte, der mit dem sog. Verfahren mit verlorener Form (verlorenes Wachs) hergestellt wurde 
(Abb. 9). Dieser Gegenstand wurde von einem der sog. Digger im Lagerareal auf einen Baumstumpf gelegt und dort liegen gelassen, da er in dem Zinngussstück wohl das eindrucksvolle Zeugnis vom Alltag der Zwangsarbeiter nicht erkannt hatte. Ähnliche, mit dem Vertreiben der Langeweile und dem Verbringen der Freizeit in der bis zu einem hohen Grade unfreundlichen, unwirtlichen und gleichzeitig monotonen Umgebung verbundene Funde sind dabei eines der Themen, deren Aussagewert in Bezug zu menschlichen Schicksalen in Zeiten der Unfreiheit bislang nicht gebührend gewürdigt wurden. Dieses Thema ist auch für die Archäologie des 20. Jahrhunderts sehr aktuell (vgl. Saunders 2003). Im Zusammenhang mit den geringfügigen, jedoch sehr zahlreichen Störungen der archäologischen Situationen büßen sie jedoch auch andere Gegenstände ihren Kontext ein, unter anderem Porzellan- und Glasgefäße und deren Bruchstücke, Metallgegenstände (z.B. Essschalen) oder Schuhreste.

Das Betriebsareal und der daran angrenzende Lagerkomplex ist eines der wenigen bislang identifizierten Objekte, an denen in Tschechien die Vorgehensweisen eines repressiven Regimes im 2. Weltkrieg - ein Thema, das vor allem in der ausländischen Literatur mehr als ausgiebig diskutiert wird - systematisch studiert werden können. Die Fundstelle bietet nicht nur Vergleichsmaterial für Untersuchungen bzgl. der eigenen Vernichtungslager und den damit zusammenhängenden zeitgenössischen Themen auf tschechischem Gebiet, sondern auch für das zunehmende Studium der von den Tschechoslowaken an den Sudetendeutschen verübten Repressalien, bzw. der Unterdrückung der eigenen Bevölkerung durch das kommunistische Regime. Nicht zuletzt schneidet die Untersuchung des Bergwerkbetriebs Sauersack und des Gefangenenlagers auch das lange stiefmütterlich behandelte Thema der Zwangsarbeit von Fremdarbeitern auf dem Gebiet des heutigen Tschechiens an. Es ist also offensichtlich, dass der vorliegende Beitrag lediglich ein erster Schritt auf einem längeren Weg ist und dass auf das fachübergreifend besetzte Forscherkollektiv auf dem Kamm der Erzgebirge noch eine Reihe Herausforderungen und dringender Aufgaben wartet.

Petr Hasil, Katedra historie Filozofické fakulty Univerzity J. E. Purkyně, Pasteurova 3544/1, 40096 Ústínad Labem, ter01hasil@seznam.cz

Mgr. David Novák, Archeologický ústav AV ČR, Praha, v. v. i., Letenská 4, 11801 Praha 1, novak@arup.cas.cz

Mgr. Jan Hasil, Archeologický ústav AV ČR, Praha, v. v. i., Letenská 4, 11801 Praha 1, hasil@arup.cas.cz 
